\title{
STUDIES ON CHALCID-FLIES OF THE SUBFAMILY LEUCOSPIDINAE, WITH DESCRIPTIONS OF NEW SPECIES.
}

\author{
By Clara Jamieson Weld, \\ Volunteer Aid, Division of Insects, United States National Museum.
}

\section{INTRODUCTION.}

While arranging the collection of Leucospidinae and Chalcidinae in the United States National Museum, a number of undetermined specimens of Leucospis and related genera were discovered. In trying to determine these it became necessary to go over the literature of the group, and the present paper is an outgrowth of the work thus started on this interesting group of parasitic Hymenoptera. The study is based not only on the material in the National Museum, but an attempt has been made to assemble all the available unworked material in the other leading American museums, specimens being borrowed particularly from Cornell University and the Academy of Natural Sciences at Philadelphia. The types of several species in the latter institution have also been studied, so that the paper represents the results of studies on practically all of the material available in this country, comprising some 36 species. Of the 14 new species here described, one is from the United States, four from Central and South America, three from India, two from China and Japan, and four from the Philippine Islands and Straits Settlements.

The last comprehensive study of this group was made by Schletterer in 1890, and his monograph has been used as the basis for the present study. At the end of the paper will be found a list of the species described since 1890 . These are arranged alphabetically by genera, with the locality indicated and with a short reference to the original description. In the bibliography which follows, a fuller citation is given and the papers are arranged chronologically under authors, bringing the literature from Schletterer to 1920 . In the treatment of the various genera in the body of the paper, references have been omitted, the purpose being simply to supplement Schletterer's paper, which should be used in connection with this in the de- 
termination of unknown material. When genera have been put in synonomy by the author, the bibliography has been included.

The author is indebted to Mr. S. A. Rohwer, Custodian of Hymenoptera, for many suggestions during the progress of the study, as well as for notes on certain types in the Philadelphia Academy, subsequently confirmed by the writer on a visit to Philadelphia before the manuscript was submitted. Since there exists in literature some confusion regarding the names applied to various structures, it has become necessary to call attention to the general external morphology, and to make figures illustrating certain characters, which are used in the key. These figures are from drawings by the author.

\section{Subfamily LEUCOSPIDINAE.}

This subfamily of the Chalcididae resembled the subfamilies Podagrioninae and Chalcidinae in having greatly swollen hind femora, which are toothed or finely dentate beneath, large coxae, and strongly curved hind tibiae. It is wholly different from Podagrioninae, however, in the structure of head, thorax, and abdomen, and is readily distinguished from the Chalcidinae by the longitudinally folded front wings, larger pronotum, abdomen, elliptical or obovate in side view, from above usually swollen behind the middle, and by an ovipositor mostly longer than the abdomen and more or less reflexed over the dorsum. The subfamily is a natural one with distinct habits, being parasitic in the nests of bees. Its distribution is general but the species are more numerous in tropical countries. Black and yellow coloring predominates sometimes accompanied by metallic tints. Of the following genera given in the key, only Leucospis and Epexoclaenoides are represented in the United States National Museum. There are four other described genera of Leucospidinae, namely, Exochlaenus Shipp, Micrapion Kriechbaumer, Exoclaenoides Girault, and Parexoclaenus Girault, which are not recognized because in my opinion the descriptions of these do not contain characters of sufficient value to justify the establishment of new genera. In 1894 Shipp transferred Leucospis anthidioides Westwood to Exochlaenus Shipp, and stated in his description of the new genus his reasons for separating it from Leucospis. If one had only a few species of Leucospis for comparison the differences stated might well seem important, but in the light of species now available, the genus Leucospis becomes broader in scope and includes all of the characters noted by Shipp, with the exception of slightly longer front coxa and 11-segmented antennae, which seem to me specific rather than generic characteristics. Dalla Torre in 1898 recognized the genus Exochlaenus and Ashmead in 1904 included it in his table of genera of the 
subfamily Leucospidinae, separating it from Leucospis as follows: "Front coxae very elongate, nearly as long as their femora, the tibiae shorter than the femora; middle tibiae with a tooth at apex; hind tibiae curved and acutely produced into a spine at apex." Measurements made of five different species of Leucospis show the front coxa to vary from 0.66 to nearly 0.90 of the length of the front femur, while the front tibia is almost always shorter than the front femur, and in all cases the middle tibia has a spine at its apex (pl. 4, fig. 23). Kriechbaumer in 1894 established the genus Micrapion with M. bitineatum, an East African species, as the genotype. He based his separation from Leucospis upon the petiolate and pear-shaped abdomen. Instead of a new genus it seems more probable that Kriechbaumer had a species of Leucospis resembling $L$. fülleborniana Enderlein or L. nyassica Enderlein, both of which have slender petiolated abdomens and are described from the same region. In a recent paper Girault has described three new genera of Leucospidinae from Queensland, Australia. Two of these Exoctaenoides and Parexoclaenus fall within the genus Leucospis but the third, Epexoclaenoides possesses minute comb-like teeth on the under side of the hind femur, a character quite distinct from anything in the genus Leucospis (pl. 2, fig. 13). Unfortunately no definite idea is given of the shape of the abdomen of Epexoclaenoides. However, from a study made from five specimens in the United States National Museum, all of one species, from Bengal, India, which agree with the generic characters of Epexoclaenoides Girault, as far as given in the description of $E$. bicinctus Girault, it seems quite probable that the abdomen of this new genus is also different from Leucospis being only about twice as long as wide in side view and nearly globular behind the third tergite, as explained in the description of Epexoclaenoides pyriformis, new species.

KEY TO THE GeNera OF LeUCOSPIDINAE.

1. Vertex with two horn-like processes in front; posterior margin of head inwardly curved; third antennal joint shorter than second; pronotum tapering toward front, scutellum heart-shaped. West Africa___Marres Walker.

Vertex without horn-like processes in front; posterior margin of head straight; third antennal segment as long as second, usually longer: pronotum of about equal width throughout; scutellum never heartshaped

2. Ovipositor limited to underside of abdomen, not even reaching end of same; abdomen more spindle-shaped, not compressed, bulging in middle with median longitudinal furrow toward posterior end of dorsum, apex pointed; central part of metathorax projecting; hind coxa with strong erect spur on upper margin. South America__________Polistomorpha Westwood.

Ovipositor not limited to underside of abdomen but reaching partially or entirely around apex and usually reflexed forward over dorsum; abdomen compressed, apex rounded: hind coxa with or without a spur on upper margin 
3. Teeth on hind femur beneath less than twenty, distinct, never minute and comb-like; abdomen elliptical or obovate in side view, compressed apically ; second and sixth tergites largest; femoral teeth variable in size and number; pronotum with or without carinae in front of its hind margin; antennae 12-segmented; labial palpi 3-segmented, maxillary palpi 4-segmented. Distribution general

Leucospis Fabricius.

Teeth on hind femur beneath more than twenty, very minute and comblike; abdomen pear-shaped, nearly globular apically; sixth tergite large Epexoclaenoides Girault.

\section{Genus MARRES Walker.}

Genotype.-Marres dicomias Walker.

This genus, established in 1841 by Walker, ${ }^{1}$ contains but a single species, which is known to the writer only from literature.

\section{Genus POLISTOMORPHA Westwood.}

G'enotype.-Polistomorpha surinamensis Westwood.

Polistomorpha was founded in 1839 by Westwood as a subgenus of Leucospis, based on the single species surinamensis. In 1860 Walker made it a separate genus when he described spegoides. Besides these two, the following species have since been described, fasciata Westwood (1874) and nitidiventris Ducke (1906). A key to these four species is given by Ducke. ${ }^{2}$ Cameron (1904) added nigromaculata, and another species is here transferred to this genus provisionally.

\section{POLISTOMORPHA (?) BULBIVENTRIS (Cresson).}

Leucospis bulbiventris Cresson, Trans. Amer. Ent. Soc., vol. 4, 1872, p. 29.

The type in the Philadelphia Academy of Science is a male (Cat. No. 1776), which makes it difficult to assign definitely the species to this genus, as the writer has never seen any of the above species and males are known of only two. There is a faint carina in the yellow band on pronotum, hind margin of scutellum is slightly angled, propodeum twice as long as metanotum and with a median carina, hind femur with a large basal and about twelve small teeth. As the basal three-eighths of abdomen (segments two and three) is constricted into a petiole which is less than half the width of the bulbous distal part, the species is provisionally transferred to Polistomorpha in spite of the lack of a spur on hind coxa.

\section{Genus LEUCOSPIS Fabricius.}

Leucospis Fabricius, Syst. Ent., vol. 1, 1775, p. 361. Genotype.-Leucospis dorsigera Fabricius.

Exochlaemus SHIPP, Ent. Mo. Mag., vol. 30, 1894, p. 245.

Genotype.-Exoclaenus anthidioides (Westwood).

${ }^{1}$ Entomologist, p. 217.

Bull. Soc. ent. France, 1906, p. 163. 
Micrapion Kriechbaumer, Berl. Entom. Zeitsch., vol. 39, 1894, pp. 315-316. Genotype.-Micrapion bilineatum Kriechbaumer.

Exoclaenoides Girault, Mem. Queens. Mus., vol. 4, 1915, pp. 356-357. Genotype.-Exoolaenoides uncinctus Girault.

Parexoclaenus Girault, Mem. Queens. Mus., vol. 4, 1915, pp. 355-356. Genotype.-Parexoclaenus vespoides Girault.

Since Schletterer's comprehensive work on this genus in 1890 thirty-three new species of Leucospis have been described, only two of which are found in the United States, while twelve of the others occur in South America. Because there is considerable confusion in literature in regard to the structural characteristics of this genus, the following morphological notes and figures are given in the hope that they may help to a clearer understanding of the structure as a whole, as well as being an aid in the use of the key and descriptions of new species included in this paper.

Head and Thorax. - The head is usually transverse with antennae inserted at about the middle of the facial line as in affinis (pl.2, fig. 6). Sometimes, however, the head is longer than wide, with antennae attached considerably above the middle of the facial line, as shown in stossonae (pl. 2, fig. 5).
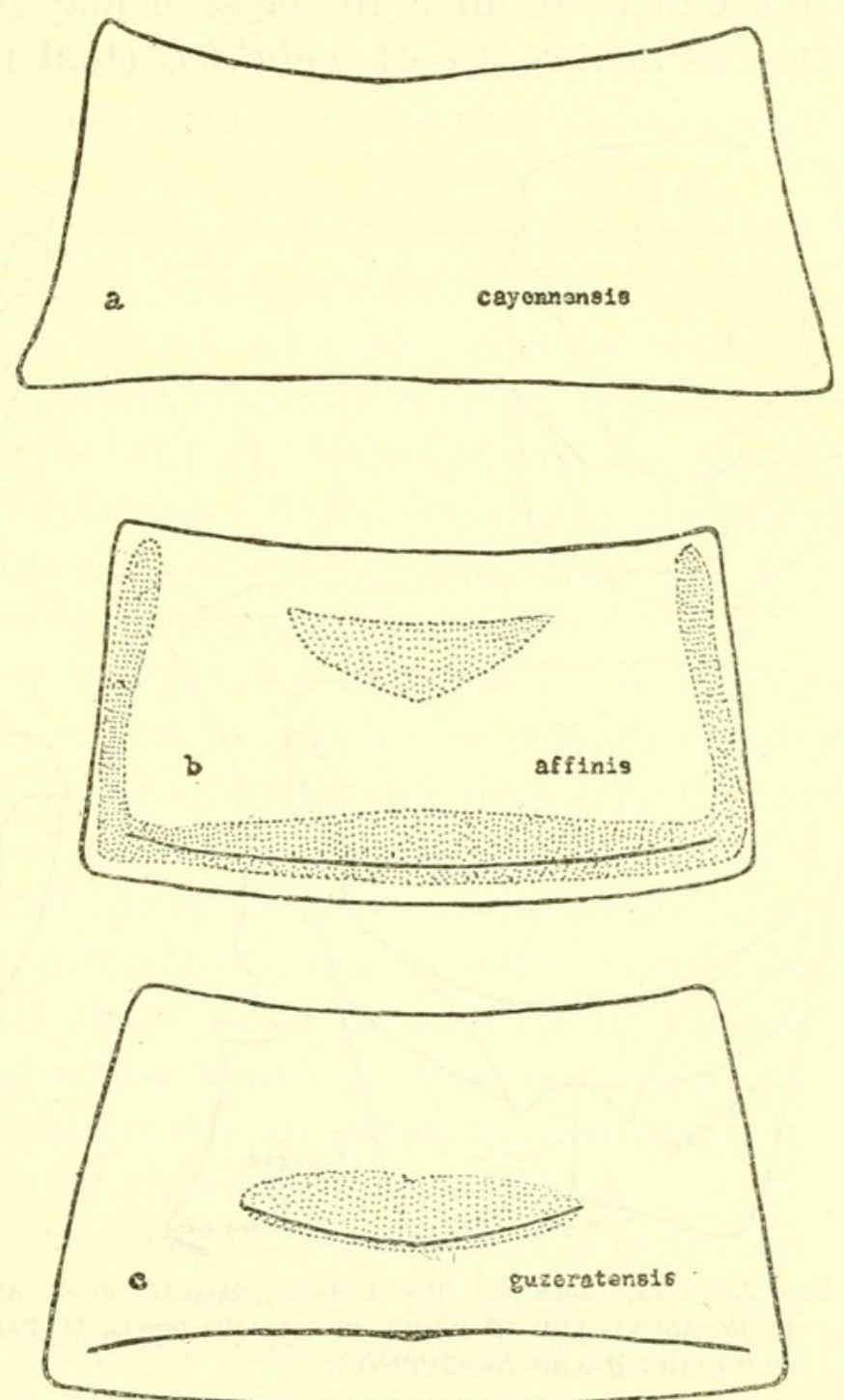

Fig. 1.-Diagrams of pronotum of Ledcospis. $a=$ CAYENNENSIS, WITHOUT ANY CARINA; $b=\mathrm{AF}$ Finis, With ONE CARINA; $c=$ GUZERATENGis, With TWO CaRinaE. The eyes are more or less sinuate opposite the middle of the scape, the scapal furrows deep, highly polished, and transversely ridged within. The antennae are 12'-segmented, with the club frequently showing one or two partial or entire sutures near its tip (pl. 1, fig. 4). The mouth parts are well developed, the mandibles 3 -toothed, the maxillary palpi 4 - and the labial palpi 3-segmented (pl. 2, fig. 8). The thorax is usually shorter than the abdomen, the pronotum large, being nearly as long as the 
mesoscutum and with or without carinae parallel to its hind margin. In cayennensis the pronotum has no carina (text fig. 1a), in affinis there is one distinct carina (text fig. $1 b$ ), and in guzeratensis (text fig. 1c) there are two well-marked carinae. The hind margin of the scutellum is always entire, the metanotum either broadly rounded behind as in affinis (text fig. $2 g$ and $h$ ) or projecting and 2 -toothed as in gigas (text fig. $2 e$ and $f$ ), the propodeum is sometimes equal in length to the metanotum as in affinis or may be twice as long as the metanotum as in the case of metallica (text fig. $2 a$ and $b$ ). The front leg
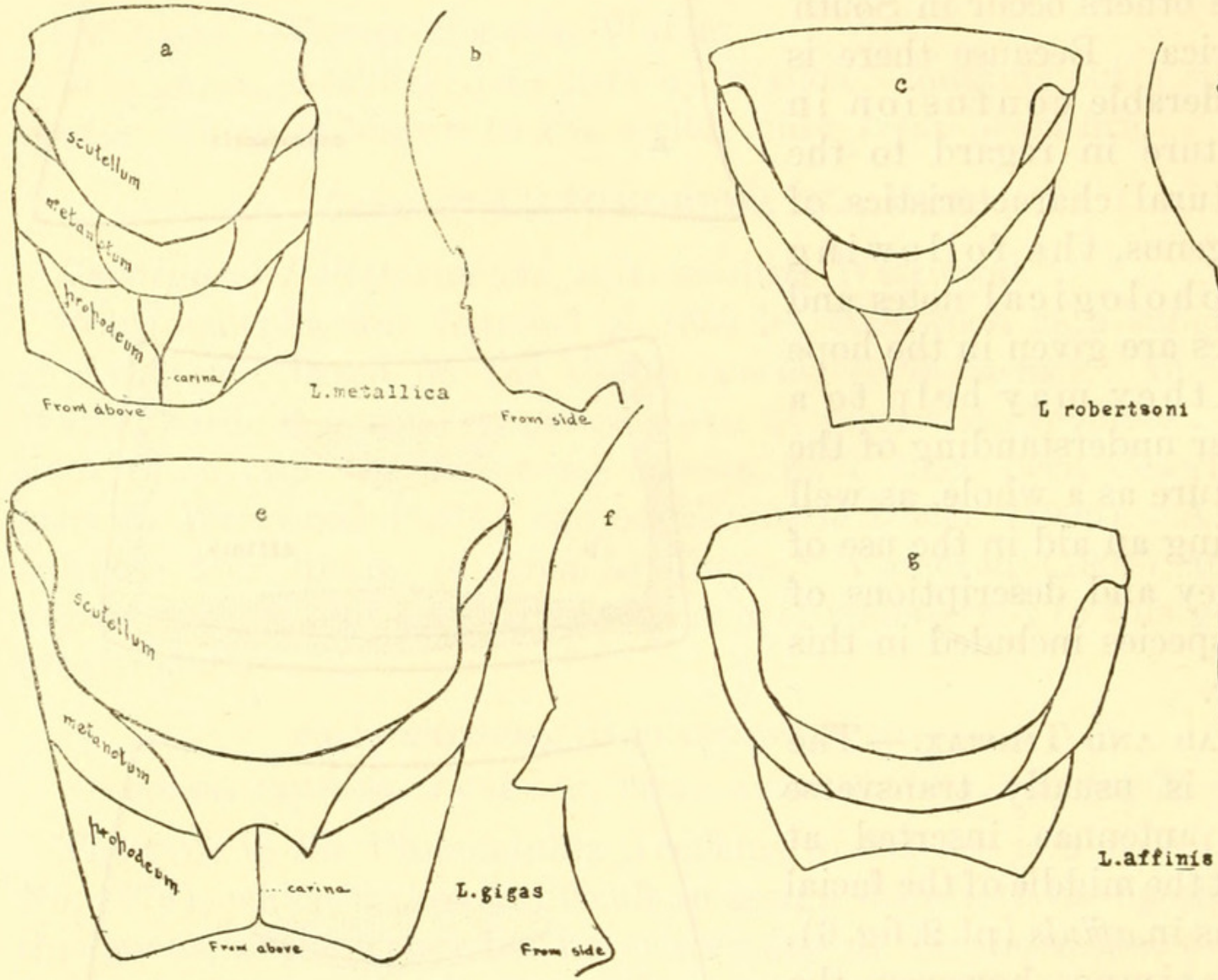

d
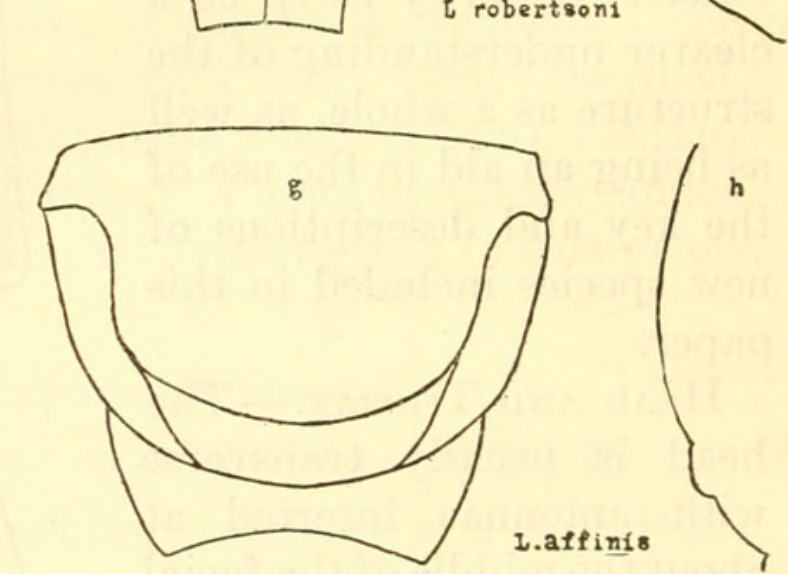

Fig 2.-Diagrams of scutellua, metanotum, and propodeum of Leucospis, viewel FROM ABOVE AND IN PROFILE. $a$ AND $b=\mathrm{L}$. METALLICA; $c$ AND $d=\mathrm{L}$. ROBERTSONI; $e$ AND $f=\mathrm{GIGAS} ; g$ AND $h=\mathrm{AFFINIS}$.

bears the usual curved forked spine near the apex of tibia beneath, and the usual comb on its metatarsus, the middle tibia bears a slender straight spine on its under side near apex, while the hind tibia bears two spines at apex beneath, one of which is stouter than the other (pl. 4, fig. 23). The hind coxae and femora are much larger than those of the front and middle legs, the hind coxa sometimes has its dorsal margin broadly rounded and entire as in cayennensis, or may have a distinct tooth as shown in affinis (pl. 4, fig. 24). The femoral teeth are quite variable both in size and number; in opalescens, for example, the basal tooth is large and followed by eleven smaller, regular teeth (pl. 2, fig. 9) while in affinis the large basal tooth is followed 
by about nine smaller and often irregular teeth (pl. 2, fig. 12). In slossonae, on the other hand, there are but five large teeth, the first two long and sharp, the next two more blunt, and the last a broad 3 -dentate tooth (pl. 2, fig. 10); still another arrangement of teeth is shown in fuliginosa (pl. 2, fig. 11), where the basal tooth is small and inconspicuous, the following five increasing in size with a broad 4-dentate tooth toward apex. The wings vary from hyaline to dark fuliginous in color, the subcostal and postmarginal veins are prominent, the radius and its branches short, leaving radial and cubital cells undeveloped, and there is only a trace of the median vein and its branches (pl. 1, fig. 2).

Abdomen.-The abdomen in Leucospis is composed of eight tergites not including the propodeum. The first is a narrow inconspicuous ringlike segment which forms a short constricted portion between the propodeum and the first apparent (second) tergite; this second tergite, which in some species is the longest, is always well developed and frequently has distinct sculpturing on its dorsal surface; the third and fourth tergites are usually constricted and telescoped together so that often the third is completely hidden but may be seen as a short segment in certain species, as for example in gigas and indiensis (pl. 3, figs. 15 and 19), while in affinis it is seldom visible except in dissection (pl. 1, fig. 3); the fourth and fifth tergites together are not as long as the second, while the sixth is usually the largest segment occupying most of the space between the constriction and the small crescent shaped spiracle-bearing seventh tergite; in cayennensis the sixth segment is about equal to the fifth and much shorter than the second, a proportion which is exceptional (pl. 3, fig. 17); the eighth tergite differs greatly in structure according to sex; in the female it forms a broad rounded portion, which consists of two similar halves reaching from near base on ventral side around apex, inclosing the ovipositor and its appendages which project from its tip (pl. 4, fig. 22); in the male the segmentation of tergites is less distinct than in the female, with more or less fusion between fourth, fifth, sixth, and seventh segments, and a small semicircular eighth segment at apex (pl. 4, fig. 26); the basal sternites in the female are short and inconspicuous, the hypopygium, which tapers toward its tip and is angled along median ventral line, occupying most of the ventral surfaces (pl. 1, fig. 1) ; the sternites in the male, on the other hand, are quite distinct (pl. 4, fig. 25). As a whole the male abdomen is more flattened and tapering toward the apex than the female. The ovipositor varies in Leucospis from a short upright spur near apex of abdomen to a long slender shaft which turns forward over the dorsum as far as the scutellum. 
KEY TO THE SPECIES OF LEUCOSPIS FABRICIUS IN THE PRINCIPAL MUSEUMS OF THE UNITED STATES.

1. Pronotum without a transverse carina parallel to its hind margin (very faint in texana)

Pronotum with one or two carinae parallel to its hind margin

2. Ovipositor a short spur or reflexed dorsally reaching forward less than one-half length of abdomen_____ 3

Ovipositor reflexed dorsally, reaching forward more than one-half length of abdomen_-_- 8

3. Hind femur with few large teeth; ovipositor a short erect spur, not reaching around apex of abdomen

Hind femur with numerous small teeth; ovipositor reflexed dorsally around apex, extending forward less than one-half length of abdomen

4. Spur between scapes prominent and coarsely sculptured like rest of face; median ocellus without parallel ridges on each side; space between lateral ocelli and eye not different in sculpture from rest of vertex, female $6.8 \mathrm{~mm}_{-}$

Spur not so prominent and not so coarsely sculptured as rest of face; median ocellus with parallel ridges on each side; striae from lateral ocelli to compound eyes; yellow transverse band near hind margin of pronotum contains a faint carina, male $6.3 \mathrm{~mm}$

5. Wings fuliginous with transparent streak longitudinally through center--- 6 Wings transparent, front edge lightly smoked_____- 7

6. Propodeum in median line twice as long as metanotum, median carina high, thin, abruptly angled behind, female $7.6 \mathrm{~mm}_{----} 3$. metallica, new species.

7. Occipital carina behind ocelli straight; united abdominal segments behind second much longer than second and longer than rest of abdomen; apical margin of sixth and following segments densely clothed with golden pile; ovipositor reaching to apical fourth of sixth segment; thorax metallic bronzy-green, without pale marking_-_-__-__-_- 4. sumichrasti Cresson. Occipital carina behind ocelli angulate forward; third, fourth, and fifth abdominal segments shorter than second or sixth; the apical margins of fifth and sixth with (rather feeble) band of silvery hair; ovipositor reaching to near base of sixth; thorax brownish black, the anterior and posterior margins of pronotum, sides and posterior margin of mesothorax yellow

5. tolteca Cresson.

8. Ovipositor reflexed, reaching forward more than one-half length of abdomen, but not to its base 9

Ovipositor reflexed, reaching forward beyond base of abdomen_________- 10

9. Propodeum with high angular median carina; hind coxa without spur on upper margin; pronotum reddish with dark spots, female $8.6 \mathrm{~mm}$.

\section{6. robertsoni Crawford.}

10. Hind coxa without spur on upper margin, its surface mostly smooth and polished; propodeum densely hairy throughout; thorax strongly greenish iridescent, without yellow markings, female $10 \mathrm{~mm}$.

7. cayennensis Westwood.

Hind coxa, with spur on upper hind margin, its outer surface entirely punctate

11. Propodeum longer than metanotum in median line; hairy only at sides, hind femur fully twice as long as broad: pronotum red except for yellow band near hind margin, female $10.8 \mathrm{~mm}$ 8. opalescens, new species.

Propodeum about equal to metanotum in medan line; hind femur scarcely twice as long as broad 
12. Metanotum rounded at apex; pronotum bluish iridescent with touch of red near front margin and a transverse yellow band near hind margin; basal tooth of hind femur large followed by eleven smaller teeth, female $9.1 \mathrm{~mm}$.

9. elegans, new species.

Metanotum truncate at apex; pronotum yellow with central area black, large basal tooth of hind femur followed by more than fourteen smaller teeth, female $8.7 \mathrm{~mm}$

10. egaia Walker.

13. Pronotum with one transverse carina parallel to its hind margin

Pronotum with two transverse carinae parallel to its hind margin

14. Ovipositor reflexed dorsally but not reaching hind margin of second (appar-

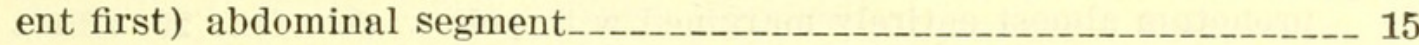

Ovipositor reflexed dorsally, reaching forward beyond hind margin of second

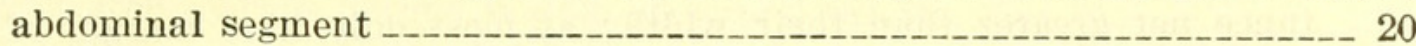

15. Metanotum two-toothed; propodeum entirely punctate with arched median carina; hind femur with large basal tooth followed by numerous smaller teeth, female $7.3 \mathrm{~mm}$

11. biguetina Jurine.

Metanotum rounded at apex; propodeum with polished light colored median spot, basal tooth (sometimes second tooth also) small, followed by three or four large free teeth and a broad four dentate one

16. Hind coxa with spur or sharp angle on upper margin; punctures numerous on second abdominal tergite and separated by a space less than their diameter

17

Hind coxa without spur; punctures few on second abdominal tergite and separated by a space greater than thei diameter.

19

17. Large sharp teeth on hind femur preceded by two very small basal teeth; distinct spur on upper margin of hind coxa, female $11.5 \mathrm{~mm}$.

12. fuliginosa, new species.

Large sharp teeth on hind remur preceded by one smaller basal tooth; hind coxa sharply angled on upper margin 18

18. Oxipositor nearly touches front margin of sixth tergite; mesoscutum with punctures gradually becoming coarser behind; its posterior half not noticeably depressed; hind femur silvery pubescent, female $10.5 \mathrm{~mm}$.

13. indiensis, new species.

Ovipositor only about three-fourths length of sixth tergite; mesoscutum with two types of sculpture, fine punctures on the arched anterior half and coarser punctures behind on the depressed flatter portion, the change of slope being marked by a narrow transverse nearly smooth area; hind femur mostly bare, female $12.7 \mathrm{~mm}$

14. banksi, new species.

19. Transverse carina in front of lateral ocelli; space between dorsal margin of scrobe and median ocellus about equal to diameter of ocellus, female $7 \mathrm{~mm}$.

15. pulchella Crawford.

20. Basal tooth of hind femur small, followed by several large teeth; hind coxa without spur.

Basal tooth of hind femur large, followed by numerous teeth; metanotum rounded behind or at most with emarginate edge

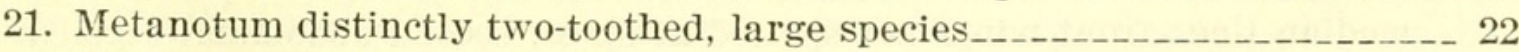

Metanotum rounded behind, small species_____-__-_-_-_-_-_-_-__-_-_ 23

22. Ovipositor reflexed dorsally, reaching forward beyond hind margin of scutellum, female $10 . \mathrm{mm}$

16. intermedia Illiger.

Ovipositor reflexed dorsally (varies from middle of second tergite to base of abdomen ) not reaching hind margin of scutellum; upper margin of hind coxa serrate posteriorly, female $12.4 \mathrm{~mm}$ 17. gigas Fabricius. 
23. Femoral teeth five; basal small, followed by three large well separated teeth and a broad tri-dentate portion; ovipositor reaches metanotum; face mostly yellow, female $6.5 \mathrm{~mm}$ 18. ornatifrons, new species.

24. Hind coxa with distinct spur on upper margin

Hind coxa without spur (margin sometimes thin and serrate) --.---.--- 28

25. Propodeum with a transverse, sparsely punctate, polished, cushion-like area near its hind margin, female $10.5 \mathrm{~mm}$

19. decorata, new species.

Propodeum without sparsely punctate polished cushion-like area near its hind margin _._- 26

26. Hind femur shining, its punctures separated by more than their width; pronotum almost entirely margined with yellow, female_- 20. affinis Say."

Hind femur dull, its punctures distinct but close and separated by a distance not greater than their width; at most only hind margin of pronotum yellow__-___-_._- 27

27. Large (8.1-10.1 mm.) ; apical abdominal segment broadly yellow; anterior ventral margin of hind femur yellow; ovipositor extends to base of propodeum

21. azteca Cresson.

Smaller $(7.1 \mathrm{~mm})$ apical abdominal segment black; hind femur unicolorous, brownish black; ovipositor extends to base of abdomen.

22. dubiosa Cresson.

28. Propodeum longer than metanotum in median line

Propodeum equal to or less than metanotum in median line_-_____-_-_ 30

29. Lateral carinae of propodeum absent and median carina not pronounced posteriorly; large light colored polished spot on outer surface of hind coxa ; metanotum emarginate, female $8 . \mathrm{mm}_{-}$

Lateral and median carinae of propodeum pronounced posteriorly, outer surface of hind coxa entirely punctuate, male $11.3 \mathrm{~mm}$.

26. japonica Walker

30. Wings dark, except at apex

Wings uniformly dark_____-_-_-_ 32

31. Color uniformly brownish, the wings dark except at apex; hind femur coarsely punctured, basal tooth largest, then six rather small teeth of nearly uniform length before the fused double tooth; hind coxa not spurred, its upper posterior angle rounded and edge thin_.-- 24. apicalis Cresson.

32. Mesoscutum with yellow lateral markings; scutellum with yellow crescentshaped marking posteriorly, female $8.7 \mathrm{~mm}$ Mesoscutum and scutellum black, immaculate, female $12 . \mathrm{mm}$.

26. japonica Walker.

33. Ovipositor reflexed dorsally, not reaching hind margin of second (first apparent) abdominal segment; abdomen in side view abruptly depressed behind

Ovipositor reflexed dorsally reaching forward beyond hind margin of second (first apparent) abdominal segment; abdomen in side view straight along dorsal line

34. Anterior transverse carina of pronotum prominent, as high as posterior in median line; front wings not spotted at apex; second abdominal segment with smooth median line, female 27. brevicauda Fabricius. Anterior transverse carina of pronotum weak, much lower than posterior in median line

a "All markings bright fiery ferruginous or reddish yellow instead of yellowish white; head without any metallic luster, etc."

Wlngs slightly yellowish; sculpture of abdomen somewhat closer and markings more extensive; pronotum practically all yellow, also scutellum; hind coxa and end of abdomen reddish (specimen determined by Cresson) --- 20b. affinis, var. poeyl Guérin. 
B5. Front wings faintly spotted toward apex; body richly marked with yellow; second tergite carinate along median line, female $7.5 \mathrm{~mm}$.

28. bakeri Crawford.

Front wings strongly spotted toward apex; body markings duller and fewer; second tergite smooth but not carinate, female $8.3 \mathrm{~mm}$.

29. maculata, new species.

36. Metanotum posteriorly produced, emarginate; body conspicuously marked with yellow; upper margin of hind coxa serrate; wings not iridescent, female 10. $\mathrm{mm}$ 30. dorsigera Fabricus.

Metanotum not produced, broadly rounded behind; upper margin of hind coxa almost entire; wings purplish iridescent

37. Ovipositor does not reach to middle of second (apparent first) tergite____-_38

Ovipositor reaches beyond middle of second tergite

38. Occipital carina wanting behind eyes; hind femur 1.75 times as long as wide; basal tooth broad and rather blunt, followed by nine teeth, female $11.2 \mathrm{~mm}$

31. bengalensis, new species.

39. Medium size $(9.1 \mathrm{~mm}$.) ; abdomen hairy, without any conspicuous marking on sixth tergite; an irregular whitish band on hind femur near base, female $9.1 \mathrm{~mm}$

32. guzeratensis Westwood.

Large (12.5-14.5 mm.); abdomen with only scattered pubescence; conspicuous yellow transverse band on sixth tergite

40. In front view lateral ocelli hidden; scutellum and hind femora immaculate, female $14.5 \mathrm{~mm}$

33. kreigeri Enderlein.

In front view lateral ocelli plainly visible; scutellum and hind femora marked with yellow, female $12.5 \mathrm{~mm}$ 34 . robusta, new species.

\section{LEUCOSPIS SLOSSONAE, new species.}

The manuscript name of slossonae given this species (male and female) by Ashmead has been retained in the following description. It is closely related to texana Cresson, having a long narrow face; obovate abdomen; short spur-like ovipositor and large semicircular hind femur, but differs in sculpture of face; darker color of wings; body markings and teeth on under side of hind femur. There is no transverse carina on pronotum in either sex of slossonae while in texana both male and female have a faint carina.

Female.-Length $7.4 \mathrm{~mm}$. A short robust species with reddish markings; face long and narrow; ovipositor very short; teeth on hind femur few and large.

Body black with following parts reddish-orange: scape; first six segments of flagellum especially on underside; two small dots on vertex near lateral margin of scrobe; wide band on posterior half of pronotum which extends forward laterally as two large spots; narrow longitudinal stripes on mesoscutum above tegulae; spot beneath base of front wings; crescent-shaped band on scutellum; metapleurae; base of femora and all of tibiae on fore and middle legs; central part of hind coxae on outer side; all of hind femora except a dark spot on outer and inner side of basal half and the black teeth; hind tibiae, with the exception of a dark stripe, on inner side; tarsi; a broad transverse spot, emarginate behind on the second tergite; a narrow 
band, angulate forward in median line, near central part of sixth tergite; ovipositor.

Head narrower than thorax behind pronotum; face black finely rugoso-punctate with scattered pubescence on frons and vertex; line from median ocellus to lower edge of clypeus nearly 1.5 times interocular space; malar space one-fifth length of eye; distance across scapal furrows at base three times distance from margin of furrow to eye; spur between scapes prominent and rugoso-punctate like rest of face; eyes sinuate; median ocellus without transverse parallel ridges on each side; space between lateral ocelli and eyes not different in sculpture from rest of vertex; postocellar distance 1.5 times ocellocular; occipital carina prominent medially, disappearing behind eyes (pl. 2, fig. 5); antennae robust 12-segmented; scape about as long as first three segments of flagellum; pedicel nearly as long as first funicular segment; second funicular twice as long as first; fourth and fifth subequal; sixth to eleventh becoming stouter; twelfth conical.

Pronotum without transverse carinae, reticulate-punctate, narrower in median line than mesoscutum; scutellum more coarsely punctate than mesoscutum, the punctures becoming shallower toward hind margin which is broadly rounded; lateral foveae of metanotum divided into pits by longitudinal striae, hind margin smooth and polished; central part of metanotum bulging and coarsely punctate, its apex rounded; propodeum twice as long as metanotum in median line, coarsely rugoso-punctate, with stout median keel, strong lateral carinae and long whitish hairs on spiracular area ; coxae of front and middle legs dark, hairy on outer surface; hind coxae dark toward base, the femoral groove mostly smooth and highly polished; hind femora finely punctate above, becoming smooth and polished beneath, about 1.5 times as long as broad, with five large teeth on ventral edge, three of which are widely separated, the fourth crowded but broad and distinct and followed by a shorter tridentate tooth; the first two free teeth are long, slender, and sharp pointed, the following two blunter at apex (pl. 2, fig. 10). Fore wings fuliginous except a narrow longitudinal streak through center which is nearly transparent; hind wings paler; veins brown.

Abdomen about equal to thorax in length, widest near middle of sixth segment, depressed toward apex, strongly compressed ventrally, forming a wedge-shaped outline in cross-section; second segment broadest behind; grooved along median line except at base, which is ridged with a cup-shaped depression on either side; following three segments short, together about one-fourth length of second; sixth large, about twice length of second, strongly depressed behind; apex rounded; ovipositor a short erect spur reaching only to hind margin of sixth tergite (pl. 3, fig. 14). 
Male.-Length 7.0-8.5 mm. Body black with markings similar to female except reddish band on sixth abdominal segment is broader and of equal width throughout, and there is sometimes a small reddish spot on median line toward apex. The abdomen is more pointed posteriorly and has a smooth depressed area in the position of ovipositor in female. On hind femur there is just a trace of a basal tooth preceding the five large teeth.

Described from 17 specimens, all but 2 of which were collected in Florida.

Type.-Cat. No. 24381, U.S.N.M. Type female, allotype, three female and six male paratypes.

One female and two male paratypes in collection of Academy of Natural Sciences, Philadelphia; one male and one female paratypes in collection of Cornell University; one male paratype in Museum of Comparative Zoology, Cambridge, Massachusetts.

Habitat.-Type-locality, Capron, Florida, April 14.

Allotype from Biscayne Bay (Slosson); paratypes from Capron, Biscayne Bay, Orlando (March 18, 1908, Russel), Miami (March 5, 1915), Gulfport (August, Renolds), Paradise Key (Mosier), Metacomba Key (March, 1898, Collins and Pollard), Tampa, Florida; and Tifton, Georgia.

\section{LEUCOSPIS TEXANA Cresson.}

This species was described from two male specimens collected in Texas (Belfrage). The type is in the Academy of Natural Sciences, Philadelphia, Cat. No. 1776, and has been seen by the writer. It lacks antennae beyond the fourth segment. The United States National Museum has the paratype, Cat. No. 1659.

\section{LEUCOSPIS METALLICA, new species.}

On account of its short ovipositor, absence of carina on pronotum and numerous small teeth on under side of hind femur, this species runs close to tolteca Cresson in Schletterer's key, but shows distinct differences in sculpture of propodeum, character of pubescence on abdomen, and in color markings.

Female.-Length, $7.6 \mathrm{~mm}$. A small iridescent species with high keeled propodeum, golden pubescence toward apex of body, and ovipositor reaching less than half the length of abdomen.

Body black with metallic tints of green and purple and few yellowish markings as follows: faint spotting on scape laterally, narrow transverse line near hind margin of pronotum obsolete at sides; slightly broader band on hind margin of mesoscutum; indistinct markings near base of femora above and under side of tibiae on front and middle legs; upper and lower margins of hind femora, except for a short distance at apex; outer side of hind tibiae. Legs, except 
where mentioned, inclined toward rufous, also area on hind coxae above.

Head nearly as wide as hind margin of pronotum; face finely longitudinally rugose-punctate, short pubescent; line from median ocellus to level of clypeus 1.2 times interocular distance; malar space one-fifth length of eye; clypeus truncate on edge; postocellar area nearly twice ocellocular; vertex broad, closely punctate; iridescent; distance across scapal furrows at base about three times distance from margin of furrow to eye; occipital carina prominent, angulate forward; eyes only slightly sinuate; antennae piceous, 12-segmented, slightly ferruginous beneath; first funicular segment only slightly longer than pedicel, second about twice first; third, fourth, and fifth subequal, rest becoming stouter, apical segment conical with indistinct suture near tip.

Pronotum contiguous punctate, without a transverse carina near its hind margin; mesoscutum about 1.3 times length of pronotum; scutellum withont yellow markings, apex broadly rounded; metanotum with parallel longitudinal ridges in foveae separated by deep punctures, its lateral margins broad and polished, apex crescent-shaped with margin smooth entire and slightly upturned; propodeum twice as long as metanotum in median line, with high thin median heel obliquely angulate behind, laterai carinae prominent (text fig. $2 a$ and $b$ ). (Paratype specimen has a high arched median carina.) Hind coxa evenly punctate above, upper margin thin and sharply angled, but without spur; hind femur 1.7 times longer than wide, closely punctate, its basal tooth beneath broad, blunt, and followed by eleven smaller teeth, the first six of which are distinctly separated, the rest smaller and crowded close together. Fore wings fuliginous, except for a hyaline streak longitudinally through center; hind wings slightly paler.

Abdomen about length of head and thorax together, densely pubescent behind fourth tergite, the hind margins of fifth and sixth fringed with hairs and apex covered with long golden pubescence; seen from above the fourth tergite is slightly constricted, the sixth swollen and the apex compressed; seen from the side the dorsal line is arched. Ovipositor reflexed over dorsum to a little beyond middle of sixth tergite, its groove reaching to apex of fifth.

Described from two specimens. Type female, one female paratype. Type.-Cat. No. 24382, U.S.N.M.

Habitat.—South America: Sao Paulo. (December 12 and 26, 1902, Beron.)

\section{LEUCOSPIS SUMICHRASTI Cresson.}

Described from one female collected by Professor Sumichrast in Mexico. 
Type-Cat. No. 1798 in the Academy of Natural Sciences, Philadelphia, where it has been seen by the writer.

\section{LEUCOSPIS TOLTECA Cresson.}

Described from four females and one male collected in Mexico by Professor Sumichrast.

Type.-Cat. No. 1801 in the Academy of Natural Sciences, Philadelphia, where they have been seen by the writer.

\section{LEUCOSPIS ROBERTSONI Crawford.}

Leucospis robertsoni Crawford Proc. Ent. Soc. Wash., vol. 11, 1909, pp. 51-52.

Described from one female and two males from Southern Florida. Diagram of scutellum, metanotum and propodeum shown in text, figure $2 c$ and $d$.

Type.-Cat. No. 12581, U.S.N.M.

\section{LEUCOSPIS CAYENNENSIS Westwood.}

This species is represented in the United States National Museum by nine females collected from the following localities: Brazil, Santarem; Panama, Corazal, Canal Zone (June 11, Busck), Porto Bello (Mar. 19, 1911, Busck), Tabernilla, Canal Zone (July 23, 1907, Busck); Guatemala, Livingston (Barber and Schwarz), Cayuga (February, Schaus and Barnes), (Oct. 15, Schaus); Honduras (Mann). The Academy of Natural Sciences, Philadelphia, has a female from Costa Rica (June 21, 1903, Crawford), which the writer has determined as this species.

Diagram of pronotum shown in text, figure $1(a)$; abdomen on plate 3 , figure 17 ; hind coxa on plate 4 , figure 24 .

\section{LEUCOSPIS OPALESCENS, new species.}

In Schletterer's key this species runs nearest to cayennensis Westwood, because of its long ovipositor and the absence of transverse carinae on the pronotum, but the two are so different in general appearance that they could not be confused. It also resembles robertsoni Crawford, from which it differs in having a low median keel on the propodeum and a spur on the upper margin of hind coxa. In Roman's key to South American species it runs to egaia Walker, but has a wider propodeum, a different shaped metanotum, and a more rotund hind femur. In structure it is most closely related to formosifacies Strand, an Argentine species. There are, however, such distinct differences in coloration that a separation seems advisable.

Female.-Length $10.8 \mathrm{~mm}$. A reddish irridescent species richly marked with yellow; ovipositor longer than abdomen; hind coxa with prominent spur on upper margin.

20107-22-Proc. N. M. vol. $61-5$ 
Body parti-colored with red, green, and purple metallic tints and yellow markings, as follows: Scape; transverse band near hind margin of pronotum, interrupted at median line; band on hind margin of mesoscutum; two conspicuous pear-shaped lobes connected in median line on hind margin of scutellum; semicircular spot on metanotum; triangular area on mesopleurae; broad interrupted band near hind margin of second tergite; narrower band on sixth parallel to its posterior margin and turned forward on sides below ; irregular crescentshaped markings just behind spiracles and similar markings near apex of abdomen; narrow stripes on front femora and on middle tibiae, with an elongate spot on upper margin of middle coxae; a stripe on upper margin of hind coxa and a spot near base on lower side; band along dorsal margin of hind femur, a line just above teeth on ventral margin, which broadens to include large basal tooth, continues to base of femur, and forms on under side a broad central band to apex. Legs, except where mentioned, reddish-brown; tibial spurs yellow; ovipositor rufous with almost black tip; antennae reddish-brown.

Head as wide as pronotum, wider than abdomen; copper-colored with rich metallic luster, finely rugosely punctate, short pubescent; distance from median ocellus to lower edge of clypeus a little longer than the interocular space; malar space one-third length of eye; clypeus emarginate, mandibles 3 -toothed; antennocular space greater than interantennal; eyes sinuate, ocelli transparent; occipital carina distinct, continuous behind eyes; scape more than twice as long as broad, first funicular segment tapering toward base, 1.5 times pedicel; second funicular longest, fourth, fifth, and sixth subequal, seventh to twelfth becoming stouter. Pronotum reddish copper-colored, finely reticulate-punctate, without transverse carina ; mesonotum and mesopleura brilliantly iridescent with greenish purple tints; mesosternum polished; scutellum more coarsely punctate than mesoscutum, broadly rounded at apex; foveae of metanotum striately punctate, apex crescent-shaped, slightly projecting with smooth upturned nearly transparent margin; propodeum slightly longer than metanotum in medium line, much longer at sides, its median carina low, its hind margin finely, shallowly, punctate with apex emarginate; spiracular areas surrounded by long whitish hairs. Hind femora shining, densely punctate, 2.3 times as long as broad, basal tooth on under side large, long, forward of middle and followed by eleven smaller black teeth (pl. 2, fig. 9); hind coxae closely punctate, with thin blunt transparent spur on upper margin toward base. Fore wings subhyaline, fuliginous along front margin and at apex; hind wings nearly transparent, veins brown.

Abdomen setigerous punctate, 1.5 times longer than head and thorax together, second tergite 1.3 times as long as wide, with two 
furrows above on either side on median line, which diverge toward triangular polished spot at base; area between furrows arched, with narrow polished median line; third and fourth tergites short, constricted; fifth scarcely one-fourth length of sixth; sixth shorter than first, swollen toward middle, its dorsal surface greenish iridescent; apex of abdomen strongly compressed. Ovipositor flattened toward apex, reaches a little beyond middle of propodeum.

Described from one female collected at Chapada in March.

Type.-Cat. No. 24383, U.S.N.M.

Habitat.-Brazil; Chapada.

\section{LEUCOSPIS ELEGANS, new species.}

In Roman's key this species runs to egaia Walker, from which it differs in shape of metanotum, femoral teeth and in color markings. It also resembles opalescens, new species, but shows distinct differences in length of propodeum, shape of metanotum, wider hind femora and in general coloration.

Female.-Length $9.1 \mathrm{~mm}$. An iridescent species with yellow markings, pronotum without transverse carina, hind coxae spurred and ovipositor longer than abdomen.

Body varicolored, ground color dark with blue-green and red metallic tints and yellow markings as follows: transverse complete band near hind margin of pronotum; shorter incomplete band of similar width on hind margin of mesoscutum; narrow band near hind margin of scutellum; median crescent-shaped spot on metanotum; triangular spot on mesopleura beneath tegula; faint oblique line on metapleura; stripes on front legs along upper and lower margins of femur, inner surface of tibia; apex above and half of margin beneath of middle femur and under side of tibia; narrow stripe along upper margin of hind coxa, which covers spur, and spot near base beneath; broad band on lower front margin of hind femur, which extends from base nearly to apex and covers large basal tooth, band along upper margin narrowing toward base and an elongated spot near apex beneath; broad band on hind margin of second tergite interrupted in median line; a band of about same width on seventh, which extends over a small portion of eighth segment in median dorsal line. Scapes are rufous in color, as are also the tegulae and front margin of pronotum, especially at sides and near middle. Legs, except where mentioned, rufous to dark brown.

Head brilliantly iridescent with garnet, gold, and green tints; face finely rugosely punctate, short pubescent; line from median ocellus to level of clypeus only slightly longer than interocular space; malar distance about one-third length of eye; clypeus sinuate at edge; eyes sinuate; vertex broad closely punctate, postocellar space 1.6 times ocellocular; occiput concentrically striate below, carinate 
above; antennae broken at third segment; scape more than twice as long as wide, first funicular segment 1.2 times pedicel.

Pronotum contiguous punctate without transverse carina; mesoscutum about 1.5 times length of pronotum in median line; scutellum broadly rounded behind; foveae of metanotum contain parallel ridges with depressions between, hind margin of metanotum finely punctate laterally almost to edge, which is narrowly polished, apex crescent shaped, slightly projecting over propodeum, with upturned edge; propodeum about equal to metanotum in median line, much longer laterally; spiracular area covered with long silvery hairs. Hind coxa with outer surface entirely punctate, a broad, thin blunt spur on upper margin toward apex; hind femur 1.8 times as long as wide, basal tooth large, margined and followed by eleven smaller teeth, the first six well separated from each other, the rest becoming crowded. Fore wings subhyaline, clouded along costal margin and toward apex with paler streak through central area; hind wings paler.

Abdomen a little longer than head and thorax together, seen from above constricted in fourth tergite, swollen in sixth, and compressed toward apex; seen from side view abdomen is straight dorsally and broadly rounded at apex; second segment of abdomen is nearly 1.3 times as long as wide, with two furrows above, which diverge toward base and are separated by a dull median carina; third, fourth, and fifth segments short, sixth shorter than second segment. Ovipositor reaches nearly to middle of propodeum.

Described from one female loaned by Cornell University.

Type.-At Cornell University.

Habitat.-South America: Argentine, La Rioja (E. Giacomelli).

10. LEUCOSPIS EGAIA Walker.

Leucospis egaia Walker, Roman; Arkiv. f. Zool., vol. 12, no. 19, 1920, pp. 8-9.

Type of this species a female collected by Mr. Bates at Ega, Brazil, is in the British Museum. The United States National Museum contains one female from Obidos, Amazonas (H. Rolle), determined from literature as this species.

\section{LEUCOSPIS BIGUETINA Jurine.}

One female in the United States National Museum obtained through exchange from Cornell University (Lot 326. Sub. 2). Abdomen shown on plate 3 , figure 18 .

12. LEUCOSPIS FULIGINOSA, new species.

In Schletterer's key this species runs close to micrura Schletterer, but differs in shape of face, comparative length of antennal segments, form of hind femur and character of femoral teeth. 
Female.-Length $11.5 \mathrm{~mm}$. A shining black and yellow species with fuliginous wings, ovipositor less than half the length of abdomen and basal tooth of hind femur inconspicuous.

Yellow markings on body as follows: upper half of scape; front and hind margins of pronotum strongly, lateral margins weakly; transverse crescent-shaped spot near middle of mesoscutum and lines above tegulae; large bilobed marking near hind margin of scutellum; a median spot on propodeum; wedge-shaped spot on metapleura; two conspicuous marks on outer side of hind femur, one of which extends from base to second tooth, the other from apex along upper margin about half way; short lines near apex of hind tibiae opposite spurs; most of dorsal surface of second tergite, except toward base; a wide transverse band near hind margin of sixth tergite which narrows laterally. Front and middle legs and tibiae and tarsi of hind legs inclined toward rufous.

Head as wide as pronotum; face finely rugosely punctate, short pubescent; line from median ocellus to level of clypeus 1.1 longer than greatest distance between eyes; malar space 0.22 length of eye; vertex broad closely punctate with polished striated area about median ocellus and on either side of lateral ocelli; clypeus sinuate with small polished tooth in median line; eyes slightly emarginate; postocellar space 1.5 times ocellocular, occipital carina distinct; antennae 12-segmented slightly ferruginous at apex, first funicular segment 1.5 times pedicel, third and fourth subequal, rest becoming stouter, apical segment conical with faint concentric rings near tip.

Pronotum contiguous punctate with faint transverse wrinkles in median line near anterior margin, and a nearly complete transverse carina parallel to its carinate hind margin; mesoscutum about 1.4 times length of pronotum in median line, densely umbillicate punctate; scutellum broadly rounded behind, its apex smooth and shining; foveae of metanotum parallel ridged, punctate between ridges, hind margin polished laterally, apex rounded, punctate; propodeum nearly twice as long as metanotum, median keel prominent with area on either side polished and coarsely punctured; rugosely punctate toward lateral carinae, spiracular areas pubescent. Hind coxa punctate except in femoral groove which is mostly smooth and polished toward apex, dorsal margin has small notched spur behind middle. Hind femur 1.8 times as long as wide, setigerous punctate, its first two basal teeth small and followed by four long, sharp, widely separated teeth and a broad 4-dentate portion (pl. 2, fig. 11); hind tibiae with apex produced into a strong prominent spur from inner edge of which projects a slender spine; front and middle claws pectinate, hind claw simple with few minute teeth at base. Fore wings uniformly fuliginous, veins dark brown. 
Abdomen slightly longer than head and thorax together; seen from above constricted in fourth segment, swollen near middle of sixth and strongly compressed toward apex; seen from side abdomen is straight along dorsal line to about middle of sixth tergite, then is sharply depressed toward apex. Groove of ovipositor reaches base of sixth segment, while ovipositor itself reaches only three-fourths length of same segment.

Described from one female loaned by Cornell University (Lot 322).

Type.-At Cornell University.

Habitat.-Japan.

13. LEUCOSPIS INDIENSIS, new species.

This species resembles similis Enderlein, male, but differs in having a faint transverse carina on the pronotum, no smooth area in middle of the mesonotum, silver pubescence on face, deeply fuliginous wings and no yellow markings on scutellum, mesonotum, or hind coxae. It differs from similis Enderlein, var. feminina Strand in color markings, slightly longer ovipositor and in size and arrangement of teeth on under side of hind femora.

Female.-Length $10.5 \mathrm{~mm}$. A slender black species with whitish markings; a conspicuous polished spot on propodeum; ovipositor about one-half length of abdomen; wings fuliginous.

Body black with whitish markings as follows: narrow transverse bands near front and hind margins of pronotum; smooth polished median area on posterior half of propodeum; two small triangular spots on sides of second abdominal segment near hind margin; a narrow band near hind margin of sixth segment, and two lines on upper side of apical segment near median line; short narrow stripe near apex on upper side of front femora and along outer basal half of tibiae; small spots at base and apex of middle tibiae; a broad band irregular in width, which begins near basal tooth of hind femur and extends across front and along upper margin to apex; a stripe along outer side of hind tibiae from base to apex.

Head a little wider than front margin of pronotum; base black, densely covered with silvery pubescence, finely rugosely punctate; eyes sinuate; line from median ocellus to level of clypeus 1.1 times interocular; malar space nearly one-fourth length of eye; distance across scapal furrows at base 2.3 times the distance from margin of furrow to eye; vertex broad, closely punctate with polished striated areas on either side of lateral ocelli; postocular space 1.3 times ocellocular; occipital carina distinct medianly, disappearing behind eyes; antennae 12-segmented, scape twice as long as broad; first funicular segment 1.5 times pedicel; third, fourth, and fifth subequal, longer than wide, rest becoming stouter.

Pronotum transversely rugosely punctate, with one faint transverse carina covered by the whitish posterior band; anterior whitish band 
follows margin of pronotum and is distant about twice as far from front margin as the other band from hind margin ; mesoscutum longer than pronotum in median line; scutellum coarsely punctate, broadly rounded behind, its margin shining; foveae of metanotum punctate between parallel longitudinal striae, hind margin smooth and highly polished, apex rounded; propodeum twice as long as metanotum, polished spot divided by the low median keel, lateral carinae convergent behind, spiracular areas silvery pubescent; hind coxa mostly punctate, smooth polished area extends from apex along upper margin which is sharply angled but without spur; hind femur twice as long as wide, finely densely punctate above with silvery pubescence, nearly smooth beneath, its under margin armed with a small short basal tooth, followed by three (left femur) or four (right femur) long, sharp, widely separated, stout teeth and a less distinct broad 4-dentate tooth. Fore wings fuliginous with violaceous lustre and a transparent streak longitudinally through center; slight metallic iridescence; hind wings hyaline except anterior apical area beyond radius, which is fuliginous and slightly violet tinted; veins brown.

Abdomen hairy, about length of head and thorax together, reddish toward base; seen from above narrow in front of middle, swollen behind middle and compressed toward apex; seen from side view broadest through middle, depressed apically; second segment scarcely broader behind, longer than wide with median polished line; third, fourth, and fifth segments short, about equal in median line; sixth segment much swollen, as long as second, third, fourth, and fifth segments together; apex rounded (pl. 3, fig. 19). Ovipositor nearly touches front margin of sixth tergite, its groove deeply cut.

Described from one female received from Ramakrishna Ayyar and recorded under his number. Collected January 28, 1913, by Ponniah.

\section{Type.-Cat. No. 24384, U.S.N.M.}

Habitat.-South India: Coimatore.

\section{LEUCOSPIS BANKSI, new species.}

This species closely resembles indiensis, new species, but has the following differences in color markings, sculpture of mesoscutum, and length of ovipositor.

\section{Female.-Length $12.7 \mathrm{~mm}$.}

Body markings cream colored; spot on apical half of scape; stripe on upper side of front femur extends more than half its length, while stripe on tibia covers whole outer side; middle femur has spot at apex, middle tibia dark only on under side; broad band on hind femur more even in width than in indiensis, median spot on propodeum less distinct; small spots on sides of second tergite absent, also narrow band near hind margin of sixth tergite and spots on apical segment near median line; stripe on metapleura not found in indiensis; meso- 
scutum is depressed in posterior half with traces of parapsidal grooves, the boundary between arched and depressed regions being marked by a narrow transverse sparsely punctate area, which separates the finely punctate anterior portion from the coarsely punctured posterior region; scutellum more sparsely punctate at base than in middle and hind portion; median keel of propodeum weak behind; hind femur on outer side finely punctate, polished and mostly bare; wings darker than in indiensis with violaceous luster more pronounced.

Abdomen less hairy than indiensis, the reddish color extending from base over sixth tergite; groove of ovipositor reaches almost to front margin of sixth tergite but ovipositor only 0.77 length of this segment.

Described from one female received from C. S. Banks (December 1, 1919).

Type.-Cat. No. 24385, U.S.N.M.

Habitat.-Philippine Islands, Los Baños.

15. LEUCOSPIS PULCHELla Crawford.

Leucospis pulchella Crawford, Philippine Journ. Sci., vol. 9, No. 5, sec. D. 1914 , p. 457.

Described from one female received from C. F. Baker from Los Baños, Philippine Islands.

Type.-Cat. No. 18401, U.S.N.M.

16. LEUCOSPIS INTERMEDIA Illiger.

The United States National Museum contains one female, collected in Southern France, which has been determined by the writer, from literature, as this species. Cornell University has one female which has been available for study.

\section{LEUCOSPIS GIGAS Fabricius.}

This species is represented by three females in the United States National Museum, one from Sicilia (1858, Mann); one from Ragusa (1868, Mann) ; and one from Italy (1886, Magretti). Cornell University has one female of this species, and the Museum of Comparative Zoology at Cambridge three females (Imhoff collection), all of which the writer has seen. Diagram of scutellum, metanotum, and propodeum shown in text figures $2 e$ and $f$; abdomen shown on plate 3 , figure 15 .

18. LEUCOSPIS ORNATIFRONS, new species.

This Philippine species resembles erthrogastra Cameron quite closely, but differs in size, color markings, and teeth on under side of hind femur. 
Female.-Length $6.5 \mathrm{~mm}$. A small species with conspicuous yellow marking on face, one transverse carina on pronotum, five teeth on hind femur, and ovipositor longer than abdomen.

Body black with yellow markings as follows: scape; two large distinct kidney-shaped markings on face reaching from vertex nearly to lower level of eyes; small indistinct spots beneath insertion of antennae and obscure spot on clypeus; broad transverse bands near front and hind margins of pronotum, the former dilated at ends; marks above tegulae; two conspicuous spots near center of mesoscutum, large bilobed marking on apex of scutellum; front half of mesoand metapleurae; two faint spots on metanotum near median line; front and middle coxae beneath; apical outer half of front femur; apex of middle femur; nearly whole of front and middle tibiae; spot on upper margin of hind coxa at base and smaller spot near apex below; outer side of hind femur except teeth and a central reddishbrown area which touches margin near apex and between first and second teeth and a spot near apex beneath; apical half of hind tibiae above; two large triangular spots on second tergite, transverse band on fifth, another on sixth which becomes wider on sides beneath, obscure marking over spiracle and two crescent-shaped markings near median line on apex; tarsi. Antennae and legs except where mentioned rufous.

Head transverse, face rugosely punctate, short pubescent; line from median ocellus to lower edge of clypeus about equal to greatest distance between eyes; malar space 0.22 length of eye; distance across scapal furrow at base about twice the distance from margin of furrow to eye, clypeus and spur between scapes more finely punctate than rest of face; eyes only slightly sinuate; postocellar space 1.8 times ocellocular; occiput concentrically striate with prominent carina angulate forward above; antennae stout, 12 -segmented, scape longer than following two segments, pedicel and first funicular segment about equal, third, fourth, and fifth subequal, rest becoming stouter toward apex, club conical with suture near tip.

Pronotum shorter than mesoscutum in median line, with a transverse carina parallel to its hind margin; front half of thorax bent downward so that head assumes a position almost parallel to abdomen; scutellum broadly rounded behind; metanotum with hind margin smooth and polished, its foveae parallel-ridged, punctate between ridges, its apex slightly depressed; propodeum about equal in length to metanotum in median line, twice as long on sides, median carina wanting, lateral carinae prominent, spiracular areas hairy; hind coxa punctate except on upper half toward apex where it is smooth and polished, upper margin bluntly rounded at base becoming thin in apical half but without a distinct spur; hind femur closely setigerous punctate, 1.7 times as long as wide with five teeth on its lower margin 
the basal small and sharp, the following three much larger (second and third sharp, fourth blunt at tip) and the last a short, broad tridentate tooth. Fore wings hyaline, clouded along front margin and toward apex; hind wings clear; veins dark brown.

Seen from above abdomen is about 2.5 times as long as widest part, second tergite largest, third covered, fourth and fifth shorter than sixth, apex compressed; viewed from side the abdomen is straight along dorsal line, widest behind middle with apex broadly rounded. Ovipositor reaches metanotum.

Described from one female received from C. S. Banks.

Type.-Cat. No. 24386, U.S.N.M.

Habitat.-Philippine Islands, Manila.

19. LEUCOSPIS DECORATA, new species.

In Schletterer's key this species runs to azteca Cresson, but differs from Cresson's type in sculpture of propodeum and in color markings.

Female.-Length $10.5 \mathrm{~mm}$. A slender shining dark brown species with yellow markings, hind coxae densely hairy, and ovipositor longer than abdomen.

Body with pale yellow markings as follows: apical half of scape beneath; transverse band near hind margin of pronotum; lateral margins of mesoscutum; transverse band near hind margin of scutellum; apex of metanotum, irregular band on hind margin of propodeum; oblique stripe through central part of metapleurae with spot on upper apical margin; line on apical two-thirds of front tibiae beneath; spot near apex of middle tibiae; lower margin of hind femora broadest at base and extended as a narrow line nearly to apex and upper margin, except near base; broad transverse band near hind margin of second tergite; narrower band near hind border of sixth tergite; two conspicuous crescent-shaped marks on apex, one on either side of ovipositor. Tegulae, spots on pronotum at sides near hind margin, area beneath tegulae, hind coxae, tibiae, tarsi, and ovipositor, except tip, reddish brown.

Head as wide as pronotum behind; face finely rugosely punctate, with metallic green and purple luster, especially on vertex and occiput; line from median ocellus to level of clypeus 1.1 times longer than greatest distance between eyes; malar space 0.25 length of eye; postocellar distance 1.3 times ocellocular; eyes sinuate opposite middle of scape; occiput transversely striate-punctate, with low carina above; antennae piceous, slightly ferruginous beneath and at tip, 12-segmented, first funicular segment about twice as long as pedicel, third, fourth, and fifth funicular segments subequal, rest becoming stouter, apical segment conical with two faint concentric sutures near tip. 
Pronotum contiguous punctate with one transverse carina parallel to its carinate hind margin; mesoscutum about 1.5 times as long as pronotum; scutellum with a transverse sparsely punctate polished band near its smooth, broadly rounded apex; hind margin of metanotum rounded, its foveae finely reticulate punctate within, with margins highly polished; propodeum about length of metanotum in median line, median and lateral carinae absent, transverse area near hind margin mostly bare and highly polished, spiracular area pubescent; hind coxa setigerous punctate, the hairs long and silvery, upper margin with a slender, sharp spur; hind femur nearly 2.5 times as long as wide, densely punctate except on yellow areas, where punctures are scattered and shallow, basal tooth on under side large and prominent, followed by a row of 10 smaller teeth, the first of which is small and inconspicuous, the next four increasing in size and well separated, the remaining five becoming smaller and crowded; front and middle claws pectinate; hind claws simple, with a few minute spines at base. Wings fuliginous, pale behind, veins brown.

Abdomen seen from above is constricted behind second tergite, swollen through sixth and compressed apically; the second segment is about 1.5 times longer than wide, its median surface elevated, smooth and polished but not carinate; seen from side view abdomen is longer than head and thorax together, with straight dorsal line and apex broadly rounded. Ovipositor reaches apex of scutellum, its tip black and compressed.

Described from two female specimens.

Type.-Cat. No. 24387, U.S.N.M. Type and paratype.

Habitat.-Type locality; Costa Rica: Juan Vinas (Schaus); Paratype, Guatamala : Amatillan (February, 1912).

\section{LEUCOSPIS AFFINIS Say.}

Leucospis affinis, Say, Graenicher, Bull. Wisc. Nat. Hist. Soc., n. s., vol. 4, 1906, pp. 153-159, 1 pl.

This is the commonest and best-known species in the United States (pl. 1, fig. 1) and the only one whose habits and life history have been studied in detail (Graenicher, 1906). It is widely distributed and is represented in the United States National Museum from the following localities: Massachusetts, Southampton (July 14, 1894); Connecticut, Hartford (July 12, 1896), Lyme (June 28, 1915) ; Pennsylvania, North East (July 8, 1916, Cushman), Highspire (June 27, 1908, Fisher), Carlisle Junction (July 1, 1909, Walton), Inglenook (June 20, 1909, Myers) ; Virginia, Vienna (July 27, 1912, Cushman), Falls Church (September 1, 1915, Greene) (September 15, 1917, Champlain), East Falls Church (June, 1916, Rohwer), Rosslyn 
(Smith); Washington, D. C. (September 15, 1878, Cresson determination) ; Maryland, Beltsville (June 25, 1915, Shannon); Texas, Dallas (July 3, 1907, Cushman) (September 4, 1907, Pierce), Devils River (May 5, 1907, Bishopp), Sweet Water (Bishopp); Indiana (Baker); Illinois, Algonquin (Baker); Wisconsin; Kansas, Riley County (September, Marlatt); Minnesota; Colorado (Baker); Arizona, Hot Springs (June 26, Barber) ; New Mexico, Las Cruces (Cockerell); California, Los Angeles (Coquillet); Oregon, Ashland (March 31, 1919, Sergent); Canada (Baker).

The Academy of Natural Sciences, Philadelphia, has representatives of this species from: New Jersey, Lawnside (September 3, 1904), Mount Pleasant (August, 1908), Riverton (August 2) ; Pennsylvania, Pike County (July, 1910); Maryland, Chesterton (August 10, 1901, Vanatta) ; Illinois; Georgia, Tifton; New Mexico, Alamogordo (May 13, 1902); Washington.

In the Museum of Comparative Zoology, Cambridge, there are specimens from Maine, Brunswick; White Mountains (Packard); Massachusetts, Taunton, Tyngahore (Blanchard), Scituate (August 28, 1906, Morse); New York, Ithaca (July), Sea Cliff (August); Maryland, Chesapeake (July 9, Banks); Virginia, Falls Church (June, July, August, Banks); and from Texas.

The Boston Society of Natural History has five Harris specimens: One female and two males, New Hampshire (36), July 23, 1835; one male (36), locality not given; one female, North Conway. N. H. (August 15, 1851). Also 16 other specimens from Maine, Bar Harbor (male, July 24, 1919, Johnson), Wales (female August, Frost) ; Massachusetts, Wellfleet (male and female, August 16, Johnson), Rutland (male and female, July 9 and 31, Johnson), Gloucester (female, July 8, Johnson), Cohasset (female, September 13, 1907, Bryant), Manomet (male, June 26, 1905, Johnson), Auburndale (female, July 22, Johnson) ; Vermont, Norwich (female, July 8, 1908, Johnson), Bennington (male, June 21, 1915, Johnson) ; Rhode Island, Tiverton (female, July 31, 1913, Johnson).

The writer has also examined specimens of affinis from Cornell University, collected from New York, Crosby Landing, Lake Keuka (June 26, 1914), Ithaca (July 4, 1914), Potsdam; Pennsylvania, Roberts (July 4, Bradley); Nevada, Lyon County (July 27, 1909).

\section{0 (a). LEUCOSPIS AFFINIS, var. FLORIDANA Crezson.}

This variety of affinis is represented in the United States National Museum by two specimens, a female from Jacksonville, Fla., and a male from Key West (Mar. 7, 1898). The writer has consulted Cresson's type (female) and paratype (male) in the Academy of Natural Sciences, Philadelphia. 
20 (b). LEUCOSPIS AFFINIS, var. POEYI Guérin.

Two specimens (male and female) of this variety from Cuba, determined by Cresson, have been seen by the writer in the Academy of Natural Sciences, Philadelphia. The yellow markings are more conspicuous than in affinis. In the female the propodeum is not as long as the metanotum, while in the male it is about twice as long.

\section{LEUCOSPIS BICINCTA Viereck.}

Leucospis bicincta Viereck, Trans. Amer. Ent. Soc., vol. 32, 1906, p. 227.

"Readily distinguished from all other American species by the pale citron-yellow, almost whitish, markings and the two bands on the abdomen, one being basal, the other in the middle.

"Male.-5 mm. Structure, sculpture, and color pattern, with the exceptions mentioned as in affinis. Upper portions of front and occiput and vertex strongly green, scape and next succeeding joint black, the joint beyond this brown (remaining joints broken off), legs black, with the following parts concolorous with the other pale markings; tips of the femora, anterior and posterior tibiae in front and middle tibiae with the upper half in front, tarsi pale brown, claws dark brown, wings faintly infuscated, the nervures black or nearly.

"Type.-University of Kansas.

"Type-locality.-Oak Creek Canon, 6,000 feet, Arizona.

"One specimen collected in July by F. H. Snow, Arizona."

The type of this species has not been seen by the writer, but from an examination of three female specimens collected in Arizona, which have almost white markings instead of yellow and which run in the key to affinis, it seems quite probable that bicincta may be a color variety of affinis.

\section{LeUCospis AzteCA Cresson.}

Described from three specimens colleeted in Mexico by Professor Sumichrast.

Type.-Cat. No. 1799 and two paratypes in the Academy of Natural Sciences at Philadelphia. Seen by writer. There is one carina on pronotum; propodeum about width of metanotum, with narrow yellow band near its hind margin, punctate like rest of propodeum; hind coxa is well covered with grayish hairs and has sharp spur on upper margin; seventh tergite yellow; apex of abdomen except along line of ovipositor yellow.

\section{LEUCOSPIS DUBIOSA Cresson.}

Described from one female collected by Professor Sumichrast in Mexico.

Type.-Cat. No. 1800 in the Academy of Natural Sciences, Philadelphia. Examined by writer. 
23. LEUCOSPIS HOPEI Westwood.

This species, said to be the most common Leucospis in Chile, is represented by three specimens in the United States National Musuem, two of which, female and male, were collected by E. C. Reed in Chile; the third specimen is a male of unknown locality.

\section{LEUCOSPIS APICALIS Cresson.}

Described from two specimens collected by Professor Sumichrast in Mexico. Seen by the writer. Shape of body resembles that of cayennensis, but is without metallic luster; carina near hind margin of pronotum prominent, angulate forward in median line; ovipositor reaches scutellum; tips of wings broadly hyaline.

Type.-Female, Cat. No. 1797 in the Academy of Natural Sciences, Philadelphia.

25. LEUCOSPIS ORIENTALIS, new species.

In Schletterer's key this species runs close to affinis Say, from which it differs in color pattern, absence of metallic luster on head, and absence of spur on upper margin of hind coxa. It is also related to japonica but differs in smaller size and in having yellow markings on mesoscutum and scutellum.

Female.-Length $8.7 \mathrm{~mm}$. A medium sized black species, without metallic luster, abdomen marked with a yellow band across middle and a broad yellow band in front and behind, hind coxa without spur on upper margin.

Body black with following parts lemon yellow: Scape; three irregular spots near front margin of pronotum and a transverse band which covers carina near hind margin; short lateral lines on mesoscutum above tegulae; bilobed spot near hind margin of scutellum; a broad interrupted band on second abdominal segment, a narrow band on fifth, a broad band on sixth, and two oval spots on apex; a triangular spot on metapleura; upper margin of hind coxa tapering toward apex, and a spot near base beneath; a large crescent-shaped marking near base of hind femur, one horn of crescent extending along upper margin and almost coalescing with spot at apex; base and apex of hind tibia; under side of front and middle tibiae and apices of front and middle femora; tarsi.

Head nearly as wide as hind margin of pronotum, face finely rugosely punctate, covered with short pubescence; line from median ocellus to level of clypeus 1.1 times interocular space; malar distance about one-fourth length of eye, clypeus sinuate with tooth in median line; distance across scapal furrows about twice the distance from margin of furrow to eye; vertex broad flat, postocular distance 1.4 times ocellocular; occipital carina distinct above, disappearing before reaching eye; antennae 12-segmented, first funicular segment about 
1.6 times pedicel, second, third, and fourth nearly equal, rest of segments becoming stouter toward apex; apical segment conical with two faint concentric rings close to tip.

Pronotum closely setigerous punctate, with one nearly complete transverse carina parallel to its margined hind border; mesoscutum more coarsely punctate than pronotum, scutellum broadly rounded behind; foveae of metanotum longitudinally striately punctate with polished hind margin, apex of metanotum rounded, its punctures few and deep; propodeum only about half as long as metanotum in median line, much broader at sides, rugosely punctate with strong lateral carinae and low inconspicuous median keel; hind coxa evenly punctate, without a spur on upper margin; hind femur less than twice as long as wide, finely punctate with twelve teeth on under margin, the first of which is largest, the following two short but well separated, the next four increasing in size, the remaining becoming smaller and semifused. Fore wings uniformly fuliginous, veins brown; hind wings somewhat paler.

Abdomen seen from above swollen behind middle, seen from side broadest posteriorly with dorsal line straight; second tergite unusually long, being 0.4 of whole abdomen; fourth and fifth together about onefourth of second, while sixth in median line is 0.4 of first; median line of second tergite is smooth and highly polished with furrows on either side which diverge toward smooth truncated area at base; no medial groove is visible on fourth, fifth, and sixth tergites. Ovipositor reaches nearly to metanotum.

Described from one specimen received from N. Gist Gee.

Type.-Cat. No. 24388, U.S.N.M. Type female.

Habitat.-China: Soochow.

26. LEUCOSPIS JAPONICA Walker.

Leucospis japonica Walker, Ashmead, Journ. New York Ent. Soc., vol. 12. no. 3, 1904, p. 147.

The United States National Museum contains three specimens, a female from Gifu, Japan (Y. Nawa), a female from Soochow, China (N. Gist Gee), and a male received from Doctor Mitsukuri, Gifu, Japan, which is evidently the specimen from which Ashmead described the male of this species and erroneously assigned a type number. (Cat. No. 7151, U.S.N.M.)

\section{LEUCOSPIS BREVICAUDA Fabricius.}

One female in the United States National Museum which was loaned for study by Cornell University and later obtained through exchange. (Abdomen shown on pl. 3, fig. 21.) 


\section{LEUCOSPIS BAKERI Crawford.}

Leucospis bakeri Crawford, Philippine Journ. Sci., vol. 9, no.5, Sec. D, 1914, pp. $457-458$.

The type, female, is in the United States National Museum, Cat. No. 18402. In his description of the female of this species, Crawford states "male unknown." Since the publication of his description (1914) the United States National Museum has received from C. F. Baker an additional female and one male collected at the type locality, Los Baños, Philippine Islands. It has also received a female taken by E. A. McGregor (June, 1918), at Cuias Panay, Philippine Islands (later sent to Cornell University through exchange) and a female collected at Manila, Philippine Islands, by C. S. Banks.

The following description of the male of this species is given to supplant the original description.

Male.-Length, $5 \mathrm{~mm}$. Resembles female of species in structure and coloration with following differences: smaller size, rufous color more suppressed; subquadrate reddish spot on disk of mesoscutum and median reddish spot on propodeum wanting, as are also the two large yellow spots on second abdominal segment, and the two small yellow spots on the spiracle-bearing (seventh) segment near apex ("fourth" of Crawford). Instead of the two elongated spots on apex of female, one on either side of the ovipositor, the male has a single large median spot on apex. There are two transverse yellow bands on the male abdomen as in the female, the front band somewhat farther behind the narrow constricted portion of the abdomen than in the female, the posterior band in about the same relative position, but not dilated so much laterally. In the type, female, there are nine smaller teeth (Crawford says about six) following the large basal tooth on hind femur, and there are probably the same number in the male, although only eight are distinguishable, on account of the position of the tibia, the last three of which are much crowded.

Habitat.-Philippine Islands, Los Baños.

29. LEUCOSPIS MACULATA, new species.

In Schletterer's key this species runs nearest to brevicauda Fabricius, but differs from it in having a large fuscous spot toward apex of fore wing, in arrangement of teeth on ventral side of hind femur, and in color markings.

Medium size; black with yellowish markings; ovipositor about onehalf length of abdomen; fore wing with fuscous spot near apex.

Female.-Length, $8.3 \mathrm{~mm}$. Body black with following parts reddish yellow : Scape; a transverse band near front margin of pronotum which dilates into triangular spots laterally; a broader band on 
hind margin which covers the posterior transverse carina; small spots above tegulae; a transverse band near hind margin of scutellum; a small spot on middle of metanotum; two narrow transverse bands on abdomen, one on constricted portion (third, fourth, and fifth tergites) and the other near posterior margin of sixth tergite; small spot on metapleura below hind wing; a streak on dorsal margin of hind coxa; spot at base and band along upper margin of hind femur; upper margin of hind tibia and all of tarsal joints; whole of first and second legs except coxae.

Head as broad as pronotum; vertex flat, broad, densely punctate; Irons narrowest opposite insertion of antennae; face silvery pubescent; line from median ocellus to lower edge of clypeus 1.1 times interocular distance; antennocular space less than interantennal; malar space one-sixth length of eye; scrobes deep, converging above, margin carinate, cavities striate; triangular spur between scapes has polished median carina; eyes slightly emarginate; postocellar space 1.5 times ocellocular; occipital carina weakly angulate forward; antennae gone except first three segments of one; scape cylindrical more than twice as long as wide. Pronotum has two transverse carinae in front of its hind margin, the posterior prominent and almost complete, the anterior much weaker, extends only short distance on either side median line; mesoscutum slightly longer than pronotum, coarsely rugoso-punctate; scutellum broadly rounded behind; lateral foveae of metanotum setigerous punctate, with smooth polished hind margins; apex projecting, strongly depressed at margin; propodeum twice as wide as metanotum, rugosely punctate, with arched median keel and strong lateral carinae; spiracular area covered with long whitish hairs. Hind coxae finely punctate without a spur on upper margin; hind femora a little over twice as long as wide, with broad blunt basal tooth on lower edge followed by twelve small teeth of which the third, fourth, and fifth are largest; hind tibiae arcuate with two distinct spurs at apex; fore wings subhyaline, darker along front margin and with large fuscous spot near apex; hind wings nearly transparent.

Abdomen seen from above constricted in front of middle, swollen behind constriction and compressed toward apex; seen from side the dorsal line is wavy, with elevations in second and sixth segments and with posterior half of abdomen strongly depressed. Second tergite longer than broad, about half the length of sixth, not carinate medianly but with a smooth shining line which broadens toward its hind margin. Ovipositor reaches three-fourths the distance to base of sixth tergite, its groove deeply cut and $\mathbf{V}$-shaped at tip.

20107-22-Proc. N. M. vol. $61-6$ 
Described from two females received from C. F. Baker. Type-Cat. No. 24389, U.S.N.M. Type and paratype. Habitat.-Island of Penang.

\section{LEUCOSPIS DORSIGERA Fabricius.}

Genotype.-The United States National Museum contains six representatives of this species from the following localities: female, St. Pauls, Tirol (1887, Schletterer) ; female, male, Transkauk, Helenendorf (1886) ; male, France; male, Italy (1880, Magretti); male, Bozen (1883).

Cornell University has three females and two males from Tangier, also a female and male the localities of which are not given. (Abdomen shown on pl. 3, fig. 16.)

\section{LEUCOSPIS BENGALENSIS, new species.}

This species resembles guzeratensis Westwood, in having two prominent transverse carinae on the pronotum, dark wings with purple iridescence, hind coxa without a spur and metanotum broadly rounded at apex; but differs in shorter ovipositor, lower occipital carina, shape of hind femora and in color markings.

Female.-Length, $11.2 \mathrm{~mm}$. A somber species with carinate pronotum, dark wings, hind coxa without spur and ovipositor reaching three-fourths length of abdomen.

Body black with following few yellow markings: apical twothirds of scape beneath; a transverse spot near center of pronotum, the hind margin of which covers the front carina; small spot on upper corner of hind coxa at base; narrow stripe on apical half of hind tibiae above; small spots on sides of fifth tergite. (In paratype specimen spots on hind coxae are wanting and there are two small dots near hind margin of sixth tergite, one on either side of median line.)

Face black covered with silvery pubescence; line from median ocellus to level of clypeus 1.1 times interocular space; malar space about one-third length of eye; clypeus sinuate at edge with small tooth in median line; spur between scapes carinate; postocellar space 1.6 times ocellocular; vertex broad; median and lateral ocelli visible from behind; occipital carina distinct medianly disappearing behind eyes; antennae 12 -segmented, first funicular segment 1.2 times pedicel; third, fourth, and fifth subequal, the rest becoming stouter toward apex.

Pronotum transversely rugoso-punctate, about the same length as mesoscutum, with two distinct carinae parallel to its hind margin which is also carinate; while both carinae are prominent in median line, the anterior extends only a short distance laterally, the posterior about three-fourths the distance to margin; scutellum 
coarsely punctate, the punctures deeply striate at apex, which is broadly rounded with smooth margin; foveae of metanotum longitudinally ridged with punctures between the ridges, hind margin polished laterally, apex bluntly rounded; propodeum rugoso-punctate, only slightly longer than metanotum, median keel low, lateral carinae prominent, apex emarginate. Hind coxa closely punctate above, without spur on upper margin; hind femur 1.7 times as long as wide, with a row of ten teeth on lower margin, the basal tooth broad and rather blunt, the second smaller, the next four increasing in size, the remaining four decreasing and becoming semifused. Wings uniformly fuscous with purplish iridescence, veins dark brown.

Abdomen a little longer than head and thorax together; seen from above slightly constricted in fourth segment, swollen near middle of sixth, compressed toward apex; seen from side view broadest behind, dorsal lines straight, apex broadly rounded; second tergite 1.1 longer than wide and about one-third the length of whole abdomen. Ovipositor reflexed over dorsum reaches beyond apex of second segment nearly one-fourth length of same, while its groove extends almost to base of abdomen.

Described from two females.

Type-Cat. No. 24390, U.S.N.M. Type and paratype.

Habitat.-Type locality, India: Bengal (June 1, 1906, T. V. R. A. Pusa Coll. 27) ; paratype from Behar (September, 1907, G. R. Dutt. Pusa Coll. 28).

32. LEUCOSPIS GUZERATENSIS Westwood.

The United States National Museum contains one female from South India: Coimbatore (Aug. 6, 1912, T. V. R.). (Pronotum shown in text fig. 1c).

\section{LEUCOSPIS KREIGERI Enderlein.}

Leucospis kreigeri Enderlein, Archiv. f. Nat., vol. 1, Heft 3, 1901, pp. $215-216$.

There is one female of this species in the United States National Museum which was received from B. P. Clark, New Guinea.

34. LEUCOSPIS ROBUSTA, new species.

In Schletterer's key this species runs near guzeratensis Westwood, but differs in larger size, shape and depth of oviposital groove, color markings and in a more swollen abdomen. It is related also to kreigeri Enderlein, from which it differs in shape of vertex, position of lateral ocelli, and in presence of yellow markings on scutellum and hind femora.

Female.-Length $12.5 \mathrm{~mm}$. A large black species with dark purplish iridescent wings, abdomen rufous toward base, pronotum strongly carinate, and ovipositor nearly as long as abdomen. 
Body black with following parts yellow: Scape; short transverse band in front of carinae on pronotum, notched in median line behind; narrow band on hind margin of scutellum slightly broader toward ends; spot on upper basal margin of hind coxa, and spot near apex beneath; spots near base and apex of hind femur; upper margin of hind tibia; small spot near apex of femur and base of tibia on front and middle legs; band near hind margin of sixth tergite, interrupted at median line and tapering laterally. Legs and base of abdomen more or less rufous.

Head nearly as wide as hind margin of pronotum; face finely rugosely punctate, covered with short silvery pubescence; clypeus emarginate with tooth in median line; lower tooth of mandible sharp pointed, second tooth broad and blunt; line from median ocellus to level of clypeus a little longer than interocular space; malar space about one-fourth length of eye; distance across scapal furrow at base over twice the distance between furrow and eye; postocellar space 1.5 times ocellocular; vertex broad, flat, closely punctate with polished striated areas on either side of lateral ocelli; occipital carina distinct only slightly bent forward in median line; antennae piceous, 12 -segmented, first funicular segment about twice length of pedicel, following four segments nearly equal, the rest becoming stouter toward apex.

Pronotum has two prominent, polished carinae parellel to its hind margin, which is also carinate; both carinae incomplete, the anterior reaches only a short distance on either side of median line; mesoscutum evenly, densely punctate; scutellum broadly rounded, hind margin smooth and polished; foveae of metanotum with two distinct ridges on either side and hind margins broadly polished, apex of metanotum rounded, slightly bulging punctate; propodeum rugosely punctate, equal to metanotum in length, no distinct median carina, lateral carinas strong, apex sinuate, polished; hind coxa finely setigerous punctate upper margin rounded and without spur; hind femur more than 1.5 times as long as wide, evenly punctate on outer surface and with under surface polished and nearly smooth, basal tooth on lower margin largest, second small and inconspicuous, following six teeth increasing, the remaining six decreasing in size, becoming fused. Fore wings fuscous, with purple metallic luster, central area lighter; hind wings subhyaline, clouded apically and along upper margin.

Abdomen longer than head and thorax together; seen from above swollen behind middle, seen from side broadest behind, apex broadly rounded; base with smooth polished truncature and two polished depressions at sides; second tergite 1.2 times as long as wide, punctate except posteriorly below, basal two-thirds reddish, 
grove of ovipositor deep, smooth, with raised margin and faint longitudinal line in bottom; third and fourth tergites short; fifth less than half sixth; sixth about 0.8 of second, coarsely punctate. Ovipositor reaches nearly to base of abdomen.

Described from two females received from C. F. Baker. Type.-Cat. No. 24391, U.S.N.M. Type and paratype. Habitat.-Singapore.

\section{Genus EPEXOCLAENOIDES Girault.}

Epexoclaenoides Girault, Mem. Queensland Museum, vol. 14, (1915) pp. $357-358$.

\section{Genotype.-Epexoclaenoides bicinctus Girault.}

Epexoclaenoides recently established by Girault is based on a single Australian species. It differs from the genus Leucospis in shape of abdomen and character of teeth on hind femur as shown in key above.

EPEXOCLAENOIDES PYRIFORMIS, new species.

This species agrees with Epexoclaenoides bicinctus Girault in having very minute comb-like teeth on under side of the hind femur, short ovipositor, simple metanotum, and hind coxa without a spur on upper margin, but differs from it in size, color, pattern, and probably in structure, although from description given, it is not possible to point our specific differences.

Female.-Length $8.1 \mathrm{~mm}$. A small black and yellow species with abdomen narrow in front, nearly globular behind, a short ovipositor and minute femoral teeth.

Body black; tegulae, middle and hind coxa, hind femur beneath, second tergite and ovipositor mostly rufous; following parts pale yellow: scape, transverse bands near front and in hind margins of pronotum, the former slightly wider in median line and dilated at margins, the latter obsolete laterally; short bands on sides of mesoscutum above tegulae; crescent-shaped markings on hind margin of scutellum sometimes interrupted in median line; central part of metapleura; apex of front femur distinctly above, slightly beneath; small spot near apex of middle femur; front and middle tibiae within; conspicuous spot at base of hind coxa on upper margin and spot below near apex; apical two-thirds of upper margin of hind femur widest at apex and a triangular spot on lower margin near base; hind tibia above; tarsi; two transverse bands on abdomen, one covering constricted portion just behind second tergite, narrow in median line much wider laterally, the other near apex, its hind margin touching groove of ovipositor.

Head transverse, as wide as pronotum, face finely rugosely punctate, silvery pubescent; line from median ocellus to level of clypeus 
about equal to greatest distance between eyes; malar space very short only one-seventh length of eye, cheeks strongly convergent, smooth polished median line on spur, distance across scapal furrow at base nearly three times distance from edge of furrow to eye; vertex broad, rugosely punctate with striated polished areas on either side of lateral ocelli and in front of median ocellus; eyes deeply emarginate; postocellar space two times ocellocular, occipital carina low; antennae 12segmented, scape about as long as following three segments, first funicular 1.3 times pedicel, third, fourth, and fifth subequal, the rest becoming stouter toward club which is conical (pl. 2, fig. 7).

Pronotum closely punctate, as wide in front as behind, with two transverse carinae parallel to its carinate hind margin, the posterior carina almost complete, the anterior short, obsolete laterally; mesonotum transversely rugosely punctate; mesosternum mostly smooth and polished; scutellum broadly rounded behind; foveae of metanotum parallel ridged with hind margin broadly polished, median area of metanotum punctate, slightly projected, its apex depressed toward middle; propodeum about twice as wide as metanotum, median carina thin, slightly arched, lateral carinae converging behind, spiracular area pubescent. Hind coxa without a distinct spur on upper margin, punctate without, mostly polished within; hind femur (pl. 2, fig. 13) triangular in shape twice as long as wide, outer surface punctate, inner smooth and polished, its lower margin angled midway with apical half very minutely toothed (more than 25 teeth). Wings transparent, veins brown; front wings clouded along postmarginal and at apex.

Abdomen pear-shaped, about as long as thorax, its second tergite narrow giving a petiolate appearance, tergites three to five short, constricted and fused in median line, the remaining tergites swollen and globular in form, the sixth tergite being much the largest and comprising nearly all of the globular portion. A narrow polished median line extends from the triangular depression at base of abdomen backward to nearly the middle of sixth tergite; hypopygium short only about one-half length of abdomen. Ovipositor short and spur-like, longer than abdomen, but not reaching dorsum; its groove just reaches around apex of abdomen. (Abdomen in dorsal and side view shown on pl. 3, fig. 20.)

Male.-Length $5.5 \mathrm{~mm}$. (head missing). Like female in structure and coloration except in following respects: smaller size; abdomen more elongate and more flattened on ventral surface; constricted portion longer; rufous color covers second tergite and extends laterally on sixth; the front yellow transverse band on abdomen is farther behind constricted region than in female, and there is a yellow median spot on apex of abdomen. 
Type.-Cat. No. 24392, U.S.N.M. Type female, allotype and three female paratypes.

Habitat.-Type locality.-India: Behar (G. R. Dutt, October, 1907. Pusa Coll. 25). Allotype: Bengal (G. M. C., March, 1908, Pusa Coll. 23). Paratypes from Bengal (G. R. D., October, 1908, Pusa Coll. 22 ; H. M. L., Nov. 2, 1906, Pusa Coll. 24; R. D. D., Oct. 17, 1908, Pusa Coll. 26).

\section{LIST OF NEW SPECIES OF LEUCOSPIDINAE DESCRIBED SINCE SCHLETTERER'S MONOGRAPH OF 1890.}

Epexoclaenoides Girault:

Epexoclaenoides bicinctus Girault (1915), p. 357, genotype_-_-_Queensland. Exochlaenus Shipp:

Exochlaenus (Leucospis anthidioides Westwood). Shipp (1894), p. 245 , genotype Brazil. Exoclaenoides Girault:

Exoclaenoides uncinctus Girault (1915), p. 356-357, genotype---Queensland. Leucospis Fabricius:

Leucospis africana Cameron (1907), p. 204 Cape Colony. Leucospis bakeri Crawford (1914), p. 457 Philippine Islands.

Leucospis bicanaliculata Cameron (1910), p. 420 Argentina. Leucospis bicincta Viereck (1906), p. 227 Arizona.

Leucospis denticoxa Strand (1911), p. 97 . Argentina. Leucospis enderleini Ashmead (1904), p. 405 Brazil. Leucospis erythrogastra Cameron (1903), p. 93 Borneo.

Leucospis feminina Strand, var. of L. similis Enderlein 1911).

p. 169

New Guinea.

Leucospis formosofacies Strand (1911), p. 95 Argentina.

Leucospis formosana Strand, var. of L. japonica Walker 1911),

p. $98-99$ Formosa.

Leucospis fülleborniana Enderlein (1902), p. 17 Africa.

Leucospis insularis Kirby (1900), p. 13 Sokotra Islands.

Leucospis japonica Walker, male described by Ashmead (1904).

p. 147 Japan.

Le ucospis kriegeri Enderlein (1901), p. 215 New Guinea.

Leucospis manaica Roman (1920), p. 5 Brazil.

Leucospis melanosa Strand, var. of L. denticoxa Strand (1911a). p. 98

Argentina.

Leucospis nigerrima Kohl (1908), p. 316

Leucospis nocticolor Strand (1911), p. 162 Soloman Islands.

Leucospis nursei Cameron (1906), p. 92 New Guinea.

Leucospis nyassica Enderlein (1901), p. 219 India.

Leucospis obscurascens Strand, var. of L. hopei Westwood (1911a), p. 99 Chile.

Leucospis pedata Strand, var. of $L$. denticoxa Strand (1911a), p. 98

Argentina.

Leucospis pulchella Crawford (1914), p. 457 Philippine Islands.

Leucospis pulchriceps Cameron (1910), p. 419

Leucospis quettaensis Cameron (1906), p. 91 Argentina.

Leucospis robertsoni Crawford (1909), p. 51 India.

Leucospis rufitarsis Strand $(1911 b)$, p. 168 Florida. New Guinea. 
Leucospis Fabricius-Continued.

Leucospis schlettereri Schulthess-Schindler (1899), p. 250 Portuguese East Africa. Leucospis simillima Strand (1911b), p. 169__________

Leucospis similis Enderlein (1901), p. 217 New Guinea.

Leucospis varicollis Cameron (1910), p. 421 Argentlua.

Leucospis violaceipennis Strand $(1911 b)$, p. 169 Mecklenburg.

Leucospis viridissima Enderlein (1912), p. 144 -Ceylon.

Micrapion Kriechbaumer :

Micrapion bilineatum Kriechbaumer (1894), p. 316, genotype Portuguese East Africa.

Parexoclaenus Girault:

Parexoclaenus vespoides Girault (1915), p. 355-356, genotype_-_Queensland. Polistomorpha Westwood:

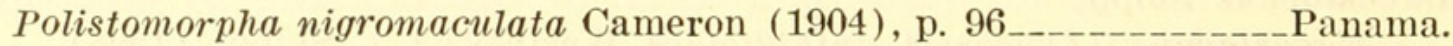

Polistomorpha nitidiventris Ducke (1906), p. 165 Brazil.

\section{BIBLIOGRAPHY OF LEUCOSPIDINAE (1890-1920).}

Ashmead, William Harris :

1899. On the Genera of the Eucharidae. Superfamily VII.-Chalcidoidea. Proc. Ent. Soc. Wash., vol. 4, no. 3, pp. 235-242.

1904a. Classification of the Chalcid Flies. Mem. Carneg. Mus., vol. 1, no. 4, pp. I-XI and 225-551. Pittsburgh.

1904b. Descriptions of New Hymenoptera from Japan.-II. Journ. New York Ent. Soc., vol. 12, no. 3, pp. 146-165.

Brues, Charles Thomas:

1918. Parasitic Hymenoptera from the British Soloman Islands, collected by Dr. W. M. Mann. Bull. Mus. Comp. Zool., vol. 53, pp. 97-130.

Cameron, Peter :

1903. Descriptions of New Genera and Species of Hymenoptera, taken by Mr. Robert Shelford at Sarawak, Borneo. Journ. Strs. Br. Roy. Asiat. Soc., no. 39, pp. 89-181.

1904. Description of a New Genus and Four New Species of Hymenoptera. Trans. Amer. Ent. Soc., vol. 30, pp. 93-96.

1906. On the Tenthredinidae and Parasitic Hymenoptera, collected by Major C. G. Nurse in Baluchistan. Journ. Bombay Nat. Hist. Soc., vol. 17, pp. 89-107.

1907a. Description of Species of Parasitic Hymenoptera, chiefly in the collection of the South African Museum, Cape Town. (Second Paper.) Ann. So. Afr. Mus., vol. 5, pp. 203-225.

1907b. On the Parasitic Hymenoptera, collected by Major C. G. Nurse in the Bombay Presidency. Journ. Bombay Nat. Hist. Soc., vol. 17, pp. 578-597.

1909. A Contribution to the Knowledge of the Parasitic Hymenoptera of Argentina. Trans. Amer. Ent. Soc., vol. 35, pp. 419-450.

Crawford, J. C. :

1909. New Chalcididae. Proc. Ent. Soc. Wash., vol. 11, pp. 51-52.

1914. New Philippine Hymenoptera. Philippine Journ. Sci., vol. 9, no. 5 Sec. D, pp. $457-464$.

Dalla Torre, C. G. DE:

1898. Cat. Hymen. Chalcididae et Proctotrupidae, vol. 5, pp. 1-598. 
DUCKE, A.:

1906. Les especes de Polistomorpha Westwood. Bull. Soc. Ent. France, pp. $163-166$.

ENDERLEIN, GÜNTHER :

1901. Neue Evaniiden, Stephaniden, Mutilliden (Apterogyna), Proctotrupiden und Chalcididen mit einer Bestimmungstabelle der afrikanischen Stephaniden. Aus dem Kgl. Zool. Mus. Berl. Archiv. f. Nat. Jahrg. 67, vol. 1, pp. 187-220.

1902. Zur Kenntnis der Insekten Deutsch-Ostafrikas. III. Uber eine von Dr. Fülleborn aus Nyassasee entdeckte neue Leucospidine. Mitteil. Zool. 'Mus. Berlin, vol. 2, pp. 1-18, 1 pl.

1912. Zur Kenntnis der Chalcididen Ceylons. (Hym.). Ent. Mitteil., vol. 1, no. 5, pp. 144-148.

Girault, Alexander A.:

1915. Australian Hymenoptera Chalcidoidea-XIV. The Family Chalcidae with descriptions of new Genera and Species. (Contrib. no. 37, Ent. Lab. Bur. Sugar Exper. Stat. Bundaberg, Queensland.) Memoirs of the Queensland Mus., vol. 4, pp. 314-365. Brisbane.

Graenicher, S. :

1906. On the Habits and Life-History of Leucopis affinis (Say). A Parasite of Bees. Bull. Wisconsin Nat. Hist. Soc., n. s., vol. 4, pp. 153-159, 1 pl.

KIRBY, F. W.:

1900. The Expedition to Sokotra XII. Descriptions of the New Species of Hymenoptera. Bull. Liverpool Mus., vol. 3, pp. 13-24.

Kohl, Franz Friedrich :

1907. Zoologische Ergebnisse der Expedition der kaiserlichen Akademie der Wissenschaften nach Süidarabien und Sokotra in Jahre 18981899. Hymenopteren. Denkschr. Akad. Wiss. Wien, vol. 71, pp. 168-301, $11 \mathrm{pl}$.

1908 in Rechinger, Karl, Botanische und Zoologische Ergebnisse einer wissenschaftlichen Forschurgsreise nach dem Samoa-Inseln, dem Neuguinea-Archipel und Salomons-Inseln. Denkschr. Akad. Wiss. Wien., vol. 81 , pp. 306-317, 1 pl.

Kriechbaumer, Jos. :

1894. Hymenoptera ichneumonidea a medico nantico Dr. Joh. Brauns in itinere ad oras Africae occidentalis lecta, enumerata et quoad nova descripta. Berl. ent. Zeitschr., vol. 39, pp. 297-318.

LiCHTENSTEIN, JEAN L. :

1919. Notes biologiques sur les Hymenopteres mediterraneens. Bull. Soc. Ent. France, pp. 147-151.

Masi, Luigi :

1916. Calcididi del Giglio, I-Toryminae, Leucospidinae, Chaldidina Eurytominae. An. Mus. Civ. Storia Nat. Genova, ser. 3, vol. 7, pp. 1-69, pl.

Roman, A. :

1920. Wissenschaftliche Ergbnisse der schwedischen entomologischen

Reise des Herrn. Dr. A. Roman in Amazonas, 1914-1915. Arkiv. f. Zool., vol. 12, no. 19, pp. 1-30.

Schletterer, August :

1890. Die Gruppe der Hymenopteren-Gattungen Leucospis Fab., Polistomorpha Westw., und Marres Walk. Berlin Entom. Zeitschr., vol. 35 , pp. 141-302, pls. 5 und 6. 
SCHAIEDEKNECHT, OTTo :

1909. In Wytsman's Gen. Insect. Hymenoptera. Fam. Chalcididae, pp. 1$550,8 \mathrm{pl}$.

SCHULTHESS-SCHINDLER :

1899. La faune entomologique du Delagoa. Hymenopteres. Bull. Soc. Vaud. Sc. Nat., ser. 4, vol. 35, pp. 249-281.

Shipp, J. W. :

1894a. Exochlaenus, Shipp. A new genus of Leucospidae. Ent. Mo. Mag., ser. 2, vol. 5, p. 245.

1894b. Notes on Chalcididae. Entomologist, vol. 27, p. 16. Strand, Embrik:

1911a. Neue und wenig bekannte exotische Arten der Chalcididengattungen Megastigmus Dalm., Merodiomorus Strand (n. g.), Polychromatium D. T. und Leucospis F. Wien. Ent. Zeit. Jahrg. 30, pp. 93-99.

1911b. Zur Kenntnis papuanischer und australischer Hymenopteren, insbesondere Schlupfwespen. Intern. Ent. Zeitschr. Guben Jahrg. 5, pp. $86-170 .^{4}$

VIERECK, H. L. :

1906. Notes and Descriptions of Hymenoptera from the Western United States. Trans. Amer. Ent. Soc., vol. 32, pp. 173-247.

t The actual pages are $86-7,89-90,97-8,103-5,114,117-8,131-2,150-1,162-3$. 168-70. 


\section{EXPLANATION OF PLATES.}

Plate 1.

Fig. 1. General view of body from side (hind leg removed) L. affinis, female.

2. Front and hing wing showing veins. L. affinis, female.

3. Abdomen dissected to show tergites 1-7 inclusive. L. affinis, female.

4. Antenna, showing segmentation. L. affinis, male.

Plate 2.

Fig. 5. Head of Leucospis slossonae (front view).

6. Head of Leucospis affinis (front view).

7. Head of Epexoclaenoides pyriformis (front view).

8. Mouthparts of Leucospis affinis, from front.

9. Hind femur of Leucospis opalescens, from side.

10. Hind femur of Leucospis slossonae, from side.

11. Hind femur of Leucospis fuliginosa, from side.

12. Hind femur of Leucospis affinis, from side.

13. Hind femur of Epexoclaenoides pyriformis, from side.

Plate 3.

Fig. 14. Abdomen in side view of Leucospis slossonae.

15. Abdomen in side view of Leucospis gigas.

16. Abdomen in side view of Leucospis dorsigera.

17. Abdomen in side view of Leucospis cayennensis.

18. Abdomen in side view of Leucospis biguetina.

19. Abdomen in side view of Leucospis indiensis.

20. Abdomen $(a)$ in side view and $(b)$ from above of Epexoclaenoides pyriformis.

21. Abdomen in side view of Leucospis brevicauda.

Plate 4.

FIg. 22. Terminal segments of Leucospis affinis with ovipositor and its appendages.

23. Front, middle and hind, tarsi of Leucospis affinis, showing tibial spines.

24. Hind coxae of Leucospis cayennensis and Leucospis affinis.

25. Sternal plate of (male) Leucospis affinis.

26. Abdomen of (male) Leucospis affinis in side view. 


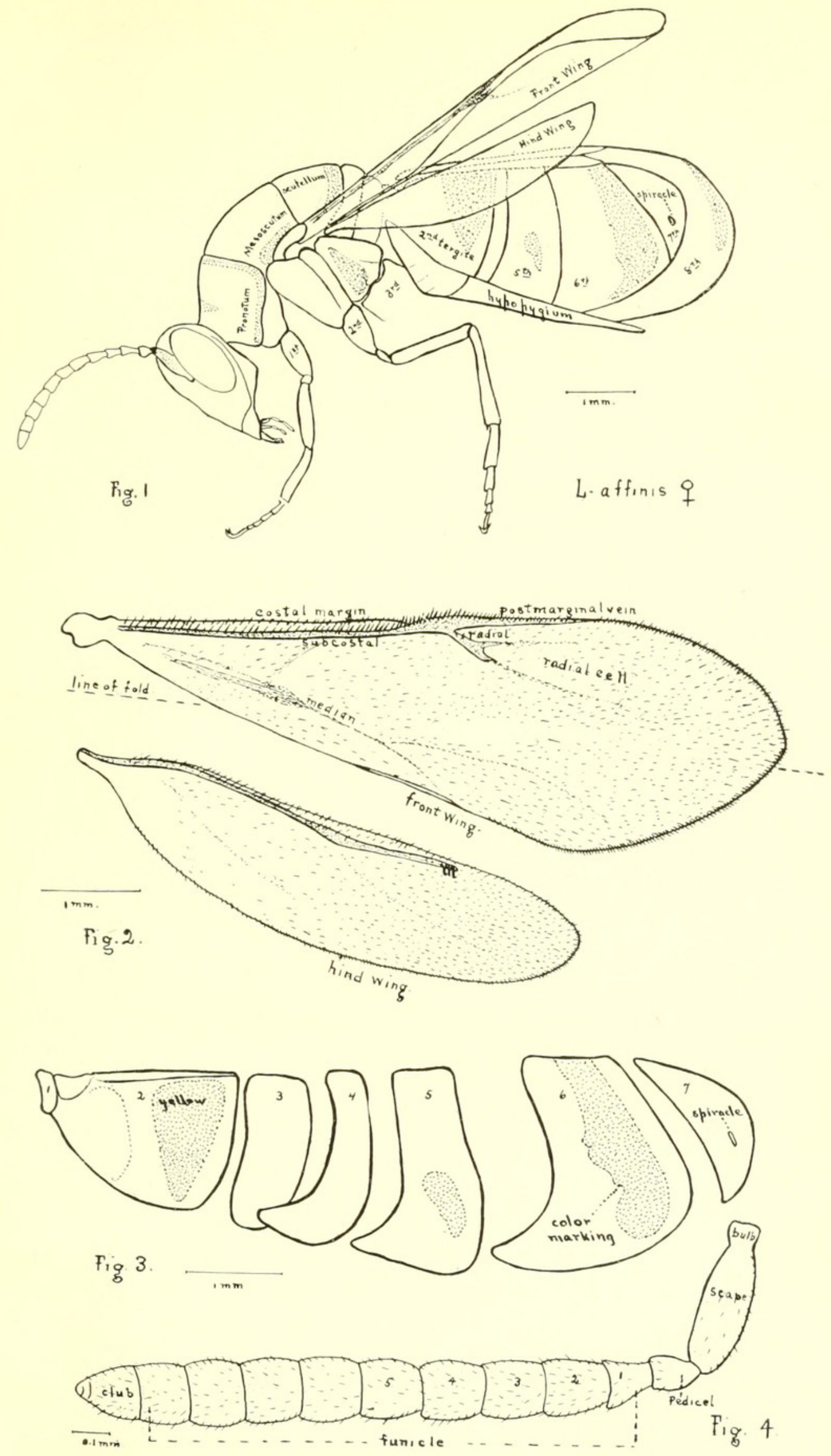

LEUCOSPIS AFFINIS.

FOR DESCRIPTION OF PLATE SEE PAGE 4 I 


\section{$2 \mathrm{BHL}$ Biodiversity Heritage Library}

Weld, Clara Jamieson. 1922. "Studies on chalcid-flies of the subfamily Leucospidinae, with descriptions of new species." Proceedings of the United States National Museum 61(2427), 1-43. https://doi.org/10.5479/si.00963801.61-2427.1.

View This Item Online: https://www.biodiversitylibrary.org/item/31797

DOI: https://doi.org/10.5479/si.00963801.61-2427.1

Permalink: https://www.biodiversitylibrary.org/partpdf/20193

\section{Holding Institution}

Smithsonian Libraries

\section{Sponsored by}

Smithsonian

\section{Copyright \& Reuse}

Copyright Status: NOT_IN_COPYRIGHT

This document was created from content at the Biodiversity Heritage Library, the world's largest open access digital library for biodiversity literature and archives. Visit BHL at https://www.biodiversitylibrary.org. 